\title{
JEZIČNI SEGMENT HRVATSKOGA NARODNOG PREPORODA ISTRE S KVARNERSKIM OTOCIMA
}

Dr. sc. Maja Polić

Hrvatska akademija znanosti i umjetnosti

Zavod za povijesne i društvene znanosti u Rijeci

Ružićeva 5, HR - 51000 Rijeka

polic@hazu.hr
UDK 811.163.42:94(497.57)

Izvorni znanstveni članak

Primljeno: 4. 10. 2017.

Prihvaćeno: 29. 1. 2018.

DOI: http://doi.org/10.21857/ydkx2crqr9

Akademik Petar Strčić

Hrvatska akademija znanosti i umjetnosti

Zavod za povijesne i društvene znanosti u Rijeci

Ružićeva 5, HR - 51000 Rijeka

pstrcic@hazu.hr

Pitanje jezika kao dio hrvatskoga narodnog preporoda pokrajine Istre s Kvarnerskim otocima intenziviralo se revolucionarne 1848. g. djelovanjem dviju struja: manjinske talijanaško-talijanske $i$ većinske hrvatske struje. Prvonavedena je zahtijevala da se u javnu službu $i$ škole umjesto službenoga njemačkog uvede talijanski jezik, dok je, suprotno njoj, postojao prijedlog da se u javni život uvede "ilirsko-hrvatski" jezik. Vezano uz jezik većine stanovnika Istre, presudna je bila i uloga biskupa Jurja Dobrile oko nakladničkih pothvata na hrvatskome jeziku. Prvi javni sudari oko navedenih dviju koncepcija dogodili su se na proim sjednicama Istarskoga sabora. Važan korak bila je i zapisnička zabilježba hrvatskom grafijom kastavskih mjesta Rukavac, Kućeli, Bregi i Pobri 1873. godine, kao i rijedak primjer da se prezime veoma borbenoga Antuna Spinčića započelo također pisati u njegovu izvorniku. Međutim, hrvatski i slovenski zastupnici u tome periodu ipak se nisu usudili i govoriti na svojem materinskom jeziku. Formalno, javno se hrvatskim jezikom progovorilo tek 1889. godine, kada je proi put potpredsjednik Sabora postao advokat dr. Ante Dukić, koji je svoj pozdravni govor održao na hrvatskom jeziku.

Ključne riječi: Hrvatski narodni preporod; pokrajina Istra s Kvarnerskim otocima; jezično pitanje, Istarski sabor, Juraj Dobrila 
Govoreći o pitanju jezika pokrajine Istre s Kvarnerskim otocima u austrijskome dijelu Habsburške Monarhije, moramo navesti dva citata koja zorno prikazuju stajalište hrvatske i talijanske strane po pitanju jezika i kulture „vieka narodnosti“, kako su XIX. st. nazivali njegovi suvremenici. Tako je vodeći istarski političar i povjesničar Carlo de Franceschi još 1846. g. pisao povjesničaru Pietru Kandleru: „Smatram da slavenski jezik neće u Istri nikada imati ljude koji će ga njegovati. To stoga, što je, kako znate, talijanski ne samo jezik predjela uz more, kao što to neki pogrešno smatraju, nego je proširen po cijeloj Istri; to je jezik svih najobraženijih slojeva, svih obrtnika, svih stanovnika u gradićima; slavenski se jezik u ovoj Pokrajini toliko osiromašio, da bez pomoći talijanskoga nije dovoljan niti za obiteljske razgovore ljudi koji su malo prosvijećeni. U Istri, ja sam najpotpunije uvjeren, nije moguća druga kultura osim talijanske.. ${ }^{\prime 2}$ Toga mišljenja taj vodeći iredentist držao se i kasnije. A imajući pred sobom toga i druge protivnike, Mate Bastian ${ }^{3}$ 1858. je godine - na prijetnju Frana Kurelca da radije prestane njihovo dopisivanje ako Bastian ne bude htio upotrebljavati kratki genitiv $\mathrm{u}$ skladu sa zahtjevima Kurelčeve filološke škole - Kurelca glatko priveo realnosti: „Tko čita njemačke novine vidi da se ne radi ni o genitivu ni o dativu, nego upravo o našem nominativu - o našem obstanku. ${ }^{\text {"4 }}$ Imajući pred sobom takva i slična mišljenja, nije čudno da je jedno od najvažnijih pitanja koja je hrvatski narodni preoporod istarsko-otočne pokrajine postavio bilo upravo jezično pitanje. Bio je to problem koji je zadirao u političku sferu, ali i u svakidašnji život naroda. Taj problem čak se drastično postavljao u Istri i na Kvarnerskim otocima i u vrijeme kada još nije bilo nekih udruženja koja bi se založila za njegovo rješenje. Jednostavno, narod nije znao drugoga jezika osim svojega, a u pokrajini Istri vladajući je bio talijanski jezik, i to ne samo u onim područjima pokrajine gdje je živjelo izmiješano stanovništvo nego i u čisto hrvatskim sredinama, pa čak i ondje gdje su stoljećima bili u upotrebi glagoljsko pismo i staroslavenska služba Božja. U Istri je, doduše, bio u upotrebi i njemački jezik, osobito do 60-ih godina XIX. stoljeća, ali on je ipak bio jezik užega birokratskog kruga režimskih organa, i već u prvoj polovici stoljeća prelazi u defenzivu - njega s uspjehom suzbija ta-

1 Nikša Stančić, Hrvatska nacija i nacionalizam u 19. i 20. stoljeću, Zagreb, 2002., str. VII.

2 Francesco Salata, Il diritto d'Italia su Trieste e l'Istria. Documenti, Torino, 1915., str. 139.

3 Petar Strčić, Mate Bastian istarski preporoditelj, političar i pjesnik, Istarski mozaik, V, 6, Pula, 1967., str. 353-365, p.o.

4 Mirko Breyer, Tragom života i rada Frana Kurelca hrvatskog preporoditelja i književnika (1811-1874), Zagreb, 1939., str. 74. O riječkoj školi Frana Kurelca usp. Diana Stolac, Riječki filološki portreti, Rijeka, 2006., str. 45 i dalje. 
lijanski jezik ne samo kao jezik koji je stoljećima dominirao u onoj polovini Istre i na Kvarnerskim otocima koji su nekoć pripadali Mletačkoj Republici već i kao pomorski i poslovni jezik znatnog dijela Mediterana. Ta gotovo „prirodna“ zamjena njemačkoga talijanskim jezikom i u službenoj upotrebi u pokrajini tekla je bez neprilika jer je i inače trajala vrlo dobra suradnja između austrijskih organa uprave i talijanaško-talijanskoga građanskog sloja pokrajine; osim toga, upravo u austrijskoj administraciji bio je zaposlen znatan broj talijanaško-talijanskih činovnika. Prema tome, za hrvatskoga čovjeka Istre i otoka, a to znači seljaka, dakle golemu većinu stanovništva, savršeno je svejedno bilo na kojemu mu se stranome jeziku gospodin obraća. U tom je smislu tadašnji ministar unutarnjih poslova Habsburške Monarhije 1848. g. imao pravo kada je time opravdavao svoje odbijanje da u pokrajini zamijeni njemački talijanskim jezikom. ${ }^{5}$ Naravno, hrvatski čovjek nije razumio ni prvi ni drugi jezik već samo svoj, materinski, a to mu je i u svakidašnjem životu stvaralo brojne teškoće, koje su mu neposredno nanosile i financijsku, pa čak i fizičku štetu. Upravo je klasičan način kako je to doslovce - na svojoj koži osjetio sam Juraj Dobrila, još kao dječak, dok je polazio nižu njemačku gimnaziju u Pazinu. S obzirom na to da još nije dovoljno poznavao njemački jezik, nije se snašao prigodom svjedočenja o nekoj nesreći svojega kolege u pazinskom potoku, pa je pazinski komesar Ludwig Kern - koji, naravno, nije poznavao hrvatski jezik - jednostavno Dobrilu (i kolegu) dao išibati. Tih petnaest udaraca zbog nepoznavanja stranoga jezika u vlastitoj domovini tako se duboko zasjeklo u Dobrilinu dušu da ih je pamtio cijeli život, a tim se slučajem koristio i u političkom radu u Saboru (20. travnja 1863.) kao primjerom koji dokazuje što to znači kada organi vlasti ne poznaju jezik naroda kojime upravljaju; ${ }^{6}$ štoviše, taj presudni događaj u Dobrilinu životu u vezi s upotrebom materinskog jezika notirali su i njegovi protivnici - suvremenici. ${ }^{7}$ Kada je Dobrila na svojoj vlastitoj koži osjetio svu težinu jezičnog problema u zavičaju, ovaj put u sudaru s njemačkom bahatošću, jezično se pitanje u Istri nije moglo postavljati zbog objektivnih razloga: $\mathrm{u}$ tom kraju rascjepkane Hrvatske, u prvoj polovini

5 Carlo De Franceschi, Memorie autobiografiche - Con Prefazione, Note e Appendici a cura del figlio Camillo, estratto dall' Archeografo Triestino, VIII, ser. III, Trst, 1926., str. 256-257. Usp. i Miroslav Bertoša, Etos i etnos zavičaja, Pula, 1985.; Nevio Šetić, Istra između tradicionalnog i modernog: ili o procesu integracije suvremene hrvatske nacije u Istri, Pazin, 1997.; Antoni Cetnarowicz, Narodni preporod u Istri (1860-1907), Zagreb, 2014.

6 Nikola Žic, Biskup Dobrila u istarskom saboru, Zagreb, 1936., str. 19. Usp. i Dr. Juraj Dobrila (1812.1882.) i stoljeće Krasne zemlje (1912.-2012.), Poreč, 2015.; Mihovil Dabo, Sve za Boga, vjeru i puk: biskup Juraj Dobrila u svom vremenu, Pazin, 2015.

7 C. De Franceschi, Memorie, n. dj., str. 193; isti, Uspomene, Pula - Rijeka, 1989., str. 165. 
XIX. stoljeća, samo rijetki pismeni, svjesni pojedinci - svećenici mogu sudjelovati u hrvatskom narodom preporodu. Jezični problem započet će dolaziti do izražaja tek onda kada započne rasti, u prvom redu, politička i pravna osviještenost hrvatskog naroda Istre i Kvarnerskih otoka, kada on počne shvaćati da je potrebno izboriti promjenu stanja u kojem nepoznavanje jezika nanosi ne samo - osjetljivu, opipljivu za svakoga pojedinca - gospodarsku, materijalnu štetu već i političku, a time i tešku nacionalnu štetu. Kad su to Hrvati shvatili - ne može se vremenski točno odrediti, ali kada je jezično pitanje svom snagom izbilo na površinu - upravo 1848. godine, vidljivo je bilo da su i šire grupe hrvatskih ljudi bile već veoma svjesne ne samo osjetljivosti nego i važnosti vrlo velikoga značenja jezičnoga pitanja, pa nam to daje za pravo da početke te borbe stavimo i u ranija razdoblja prve polovine XIX. stoljeća. To, naravno, daje i drukčije viđenje vremenskih početaka širega razvoja hrvatskoga narodnog preporoda pokrajine Istre i Kvarnerskih otoka. No, jezično pitanje - slobodna, pa službena upotreba jezika većine pučanstva pokrajine - doći će do punoga izraza nakon obnove ustavnog života u Monarhiji, kada započinje period borbi za njegovo rješavanje, posebno od 60-ih godina nadalje.

2.

Jezično pitanje u Istri započelo je iznenada i svom silinom tijekom 1848. godine, najviše kao rezultat općih revolucionarnih kretanja i zanosa zbog rušenja snažnih feudalnih ostataka i pobjedom niza građanskih težnji. Javno su to pitanje u Istri i na Kvarnerskim otocima inicirali njihovi talijanaško-talijanski zastupnici svojim danas povijesnim zahtjevom ministru unutarnjih poslova Doblhoffu dne 30. kolovoza 1848. da se i službeno u Istri uvede talijanski jezik umjesto njemačkoga, i to u upravi i školama. ${ }^{8}$ Carlo Combi i Carlo De Franceschi ${ }^{9}$ nisu to učinili sami na svoju ruku - oni su znali za raspoloženje talijanaško-talijanskog sloja u pokrajini, koji su zastupali. Bio je to, međutim, proziran politički potez, utoliko više što je nešto ranije Beč odredio da vlasti u pokrajini moraju upotrebljavati talijanski jezik kada kontaktiraju s talijanskim pučanstvom. ${ }^{10}$ Time je bilo riješeno jezično pitanje talijanskoga naroda u Istri i na Kvarnerskim

8 C. De Franceschi, Memorie, n. dj., str. 84; isti, Uspomene, Pula - Rijeka, 1989., str. 70; Božo Milanović, Hrvatski narodni preporod u Istri, sv. 1, Pazin, 1967., str. 166. U materijalima njemačke uprave Istarskog okruga, koji se čuvaju u Državnome arhivu u Pazinu, nalazi se znatna korespondencija i na talijanskom jeziku.

9 O njima usp. Istarska enciklopedija, Zagreb, 2005., str. 141, 172-173.

10 C. De Franceschi, Memorie, n. dj., str. 257; isti, Uspomene, n. dj., str. 263. 
otocima, iako ni ranije nije bilo nekih većih problema. ${ }^{11} \mathrm{U}$ igri je bilo nešto drugo, krupnije: vodeći predstavnici talijanaško-talijanskoga vladajućeg sloja u pokrajini smatrali su kao izuzetnu povijesnu šansu činjenicu što im se činilo da je Beč općenito u povlačenju; trebalo je, dakle, iskoristiti trenutačne događaje u Monarhiji, i to osobito one na Apeninskom poluotoku, te dobiti službeno priznanje Beča da je Istra talijanska zemlja; korak dalje bilo bi priključenje toga kraja apeninskim zemljama. Time su iredentistička htijenja već bila na djelu, iako se još nisu tako imenovala. Međutim, ministarstvo je 15. prosinca negativno odgovorilo utvrdivši kao činjenicu da su Talijani u Istri manjina, a da su slavenski i vlaški rod u većini, pa je talijanskom stanovništvu svejedno kojim će jezikom vlast kontaktirati s većinom. Na burna reagiranja talijanaško-talijanskih zastupnika i pojedinih sredina u Istri Beč nije reagirao. Bilo je to u skladu i s onovremenim događajima na Apeninskom poluotoku i općenito sa živim kretanjima talijanskog naroda, pa se nije moglo ni očekivati da bi Beč službeno dozvolio uvođenje talijanskog jezika u Istri; međutim, očito je da je vlada s takvim odbijajućim rješenjem računala i na Slavene iz Istre - ako se javi potreba da ih se upotrijebi protiv eventualno jačeg pokretanja talijanaško-talijanskog svijeta u Istri.

U bečki parlament bila su izabrana četiri talijanaško-talijanska i jedan hrvatski predstavnik - Josip Vlah, Kastavac, iz istočne Istre. ${ }^{12}$ Za sada se malo zna o njegovoj aktivnosti u Beču, ${ }_{1}^{13}$ međutim, u studenome je poduzeo akciju koja je ukazala na to da je i hrvatski svijet iz Istre bio znatno politiziran, a njegovi dijelovi na sjeveroistočnoj obali Istre i veoma svjesni svoje pripadnosti Hrvatskoj. Na zastupnikov prijedlog, u propagandnu agitaciju krenuo je njegov brat Martin, kastavski općinski načelnik - poveo je akciju u istarskoj Liburniji kako bi se istočna Istra pridružila tadašnjoj Rijeci; a to je u danim prilikama tada je Rijeku držao Josip Jelačić - značilo uključivanje u maticu zemlju. ${ }^{14}$

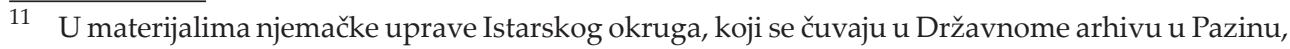
nalazi se znatna korespondencija i na talijanskom jeziku.

12 B. Milanović, Hrvatski, 1, n. dj., str. 163; Giovanni Quarantotti, La deputazione istriana alla Costituente austriaca del 1848-49. Le Nuove Provinsie, I, sv. 2, Rim, 1922., str. 47-58, p. o. O Josipu Vlahu usp.: Maja Polić, Znameniti političar i preporoditelj Josip Vlah / Josip Vlah Distinsul om politic şi promotor al renaşterii, Vlahii, Istroromânii ş Românni la Adriatică / Vlasi, Istrorumuni i Rumuni na Jadranu, Timişoara - Zrenianin, 2016., str. 154-175.

13 Fran Barbalić, Prvi parlamentarni izbori u Istri 1848., Historijski zbornik, 1, Zagreb, 1948., str. 175. O Vlahu, usp. i C. De Franceschi, Memorie, n. dj., str. 84; isti, Uspomene, n. dj., str. 70; Josip Apih, Slovenci in 1848. leto, Ljubljana, 1888., str. 135.

14 Bosiljka Janjatović, Dva pisma Josipa Bunjevca banu Jelačiću o Rijeci (31. kolovoza 1848.), Rijeka, V, 1-2, Rijeka, 2000., str. 175-187; ista, Josip pl. Bunjevac u Rijeci (31. kolovoza 1848.) te ponovno uključivanje Rijeke u Bansku Hrvatsku, Rijeka, sv. 1-2, Rijeka, 1998. - 1999., str. 39-52. 
Bitno je ovdje istaknuti da je prilikom te prve pojave organiziranog nacionalnog, preporodnog istupanja Hrvata iz Istre došao do izraza prvi put i jezični problem. Pozivu Kastavaca odazvali su se i Lovranci, i to uime cijele Liburnije - Voloskoga, Veprinca, Mošćenica i Brseča, ${ }^{15}$ oni su - uz to što su u cjelini odbili pokušaj talijanaško-talijanskih zastupnika - odlučno izjavili da u tom kraju opstoje sasvim slavenske općine, u kojima se stoljećima održava služba Božja i propovijeda na slavenskom jeziku. Na tu akciju, međutim, negativno su odgovorili Vološčanci, pa su, između ostalog, i oni isticali pitanje jezika. Oni ne osporavaju upotrebu hrvatskog jezika, štoviše, naglašavaju da kod kuće govore „,ilirski“, dakle hrvatski, ali iz ekonomskih razloga služe se i „ilirskim“ i talijanskim jezikom; međutim, službeno žele upotrebljavati samo talijanski jezik, i to zato jer je to , jedini pismeni jezik“ u Istri, a i oni su sami na njemu „znanstveno izobraženi".

Činjenica jest da se i na tome primjeru Voloskog vidi da je denacionalizacija bila na djelu, da se napuštao materinski jezik u korist gospodarskih probitaka koje je omogućavala opća situacija sa širokom upotrebom talijanskog jezika u Austrijskom primorju i šire. O tome da je talijanski jezik napredovao brzim koracima u Monarhiji, a i o tome kakav je bio odnos prema hrvatskom jeziku u Beču, govori i postupak samih Kastavaca; oni su uputili protest protiv vološčanskog protesta ministarstvu unutarnjih poslova u Kromjeriž, a svoj su odgovor stilizirali na talijanskom jeziku, sigurno vrlo dobro znajući da ga ljudi u ministarstvu znaju, što nije slučaj s hrvatskim. Ističu, uz ostalo, da se njihovi pojedini sunarodnici i braća, zbog običnog egoizma, odriču i svoje narodnosti i jezika. I sada veoma važan zahtjev Kastavaca u počecima javne i službene borbe za jezik: ministarstvo se moli da se ilirsko-hrvatski jezik i službeno prizna kao uporabni jezik u sudu, školi i u crkvi. Njihov župnik - dekan - službeno potvrđuje da se u dekanatu sve do Brseča govori samo hrvatskim jezikom. Dakle, Kastavci su tada učinili istu stvar kao i talijanaško-talijanski zastupnici, s čime je i na hrvatskoj strani jezično pitanje podignuto na vladinu razinu. Beč je odgovorio i Hrvatima; ministar je $s$ jedne strane umirio Hrvate - potvrdio je ono što je ranije odgovorio talijanaško-talijanskim zastupnicima, tj. da će se talijanski upotrebljavati samo u kontaktima s Talijanima. $S$ te je strane umirio Kastavce i ostale Hrvate sa sjeveroistočne obale Istre; jer sama država službeno i formalnopravno nije stala iza

$\overline{15}$ Petar Strčić, Liburnijska Istra u hrvatskome nacionalnom pokretu u XIX. i XX. stoljeću s posebnim osvrtom na Volosko, Časopis za povijest zapadne Hrvatske, 2-3, Rijeka, 2008., str. 73-94; Petar Strčić, Maja Polić, Čitaonički pokret u Liburnijskoj Istri, Zbornik Kastavštine, 21, Kastav, 2017., str. 13-36. 
talijanskog jezika kao službenog u pokrajini; ali, što je bilo osobito bitno, ministar nije pozitivno odgovorio ni na kastavski zahtjev. Je li moguće da je time parirao jačanju Jelačićeva autoriteta i jačanju Hrvatske u cjelini? Na sve to još su se jednom javili Lovranci pobijajući ekonomske razloge Vološčaka o njihovoj boljoj vezi s Trstom nego s Rijekom, i to ponovo ističući da svi govore „ilirski“, a samo mali dio i talijanski, koji je, uz to, naučen u tuđini. ${ }^{16}$

Prva javna pojava nacionalnog sukoba u Istri, a u okviru njega i borba za jezik, vrlo je brzo pokazala visokopolitiziranu hrvatsku preporodnu svijest o ulozi jezika i njegovu značenju u životu jednoga naroda. Očito je da je cijela jedna sredina živo pratila opća revolucionarna kretanja u Monarhiji, ali i to da je moralo biti snažnijih odjeka ilirskog pokreta, odnosno hvatskoga narodnog preporoda i u tom dijelu Istre. Međutim, događaji u području od Kastva do Brseča izazivali su i negativnu reakciju dijela poslovnih krugova iz centra uprave toga liburnijskog područja, očito iz redova onih poslovnih ljudi koji su se već počeli denacionalizirati zahvaljujući svojim intenzivnim poslovnim kontaktima i ovisnosti o talijanskome svijetu općenito. Naravno, taj hrvatski svijet još se ne srami „kućne“ upotrebe materinskog jezika, ali za njega je, očito je, talijanski jezik jezik visoke civilizacije i kulture kakvu - po njihovu mišljenju - hrvatski narod nema i ne može imati; a to je i stajalište iredentističkoga pokreta u pokrajini i izvan nje. U sukobu tih dvojnosti kretat će se i kasnije bitke za jezik.

3.

Stranci koji su prolazili Istrom susretali su se 50 -ih godina s činjenicom da se tamo govore dva jezika; spominjući svoj posjet Rovinjskom Selu, Johann Georg Kohl piše: „Svi su nas srdačno pozdravljali i to slavenskim pozdravom ‘Poh!17, te sam zaključio da tim jezikom i govore. Primijetio sam naime, da je potalijančivanje življe uspijevalo jedino u gradovima, te se je na gradove i ograničilo - svo ostalo stanovništvo izvan gradskih zidina bilo je slavensko. Južni Istriani, koliko sam primijetio, istoga su porijekla kao i Dalmatinci; oni nisu Kranjci, već Hrvato-Srbi. “18 Na taj puk misli J. Dobrila; izdavanje Dobrilina molitvenika Otče budi volja tvoja! već 1854. g. i njegovi pokušaji krajem toga, petoga desetljeća da pokrene

$\overline{16}$ Slavjanski jug, I, 61, Zagreb, 23. 12. 1848., str. 242; isto, II, 18, 10. 2., str. 70; Matko Laginja, Istranom. Književna ostavština, Rijeka, 1970., str. 63-75; B. Milanović, Hrvatski, 1, n. dj., str. 117, 170-174; Matko Rojnić, Nacionalno pitanje u Istri 1848-1849, Historijski zbornik, 2, Zagreb, 1949., str. 103-109.

17 Misli se na pojam Bog.

18 Miroslava Despot, Putopisac Johann Georg Khol o Istri, Riječka revija, I, 4, Rijeka, 1952., str. 239. 
prvu periodiku Hrvata iz Istre ${ }^{19}$ govori o praktičnoj brizi toga najistaknutijega preporodnog radnika u navedenom periodu da do puka dođe riječ na njegovu materinskom jeziku; činjenica jest da je molitvenik bio najutjecajnije preporodno štivo za cijeli niz generacija, da je i kasnije preštampavan mnogo puta; pisan je lijepim i jezgrovitim jezikom; zna se i to da je biskup Dobrila znatno pazio na jezik pri sastavljanju svoje knjižice te da se o njemu savjetovao i s drugima. ${ }^{20}$ Za sada, međutim, ne znamo je li bio upoznat s hvalospjevom i oduševljenjem zbog upotrebe hrvatskog jezika u Istarskom razvodu dvije godine ranije, ${ }^{21}$ ali zna se za oduševljavanje tim spomenikom kasnije, $u$ redovima druge generacije preporodnih djelatnika.

Ante Starčevićc ${ }^{22}$ naime konkretno je na primjeru jezika u Razvodu i upotrebe toga hrvatskog jezika ${ }^{23}$ ovako zaključivao: „Spomenik ovaj nije samo zato znamenit, što se iz njega jasno vidi, da je kod otacah naših, jezik hervatski bio sasvim služben, a ne samo služben nego i diplomatički, - još onda, kad mnogi zapadni narodi nisu ni mislili, da bi svoj na to veličanstveno mesto uzneli, premda, velim, on dokažuje, koliki je bio kod otacah naših hervatski narodni ponos, kome kod nas ni traga niema; itako, on je najzlamenitiji s toga, što nas spominje na mnoga, još puno staria, diplomatička pisma, sastavljena u hervatskom jeziku, kako se iz ovoga vidi, puno čistiem, nego li su pisma mnogih naših današnjih pisacah. Ja deržim, da ta pisma još nisu propala, nego negdi u vlastelskim pismaricam zabačena, ali kod prostoga naroda dobro spravljena leže, i mogu se dobiti, samo ako je volje i ljubavi. Zato, ufam se, da će se toga sladkoga posla primiti naši vredni istrianski otačbenici." ${ }^{24}$ Što se tiče jezika, Starčević je na primjeru Istre jasno „istaknuo svoju vlastitu polaznu točku upozorenjem da se u 'Razvodu' mješavina svih triju hrvatskih narječja i 'krainskog' naziva hrvatskim jezikom. Htio je izraziti duh hrvatskog naroda čuvanjem riječi iz svih

19 Avgust Pirjevec, Škof Juraj Dobrila buditelj hrvatskog kmeta v Istri. Dve Dobrilovi pismi Bleiweisu, Jadranski koledar za 1937., Zagreb, str. 91.

20 Vjekoslav Rubetić, Vjekopis dra Jurja Dobrile biskupa tršćansko-koparskog prije porečko-puljskoga, Zagreb, 1882., str. 58. - Savjetovao se i s F. Kurelcem. (AHAZU (Arhiv Hrvatske akademije znanosti i umjetnosti), XV-8/D1.156 i 157, J. Dobrila-F. Kurelac, Poreč, 31. 1. i 20. 11.1869.). U Arhivu za povjesticu jugoslavensku 2, Zagreb, 1852., str. 227-275.

22 O njemu usp.: Gross Mirjana, O nacionalnoj ideologiji Ante Starčevića i Eugena Kvaternika, Časopis za suvremenu povijest, 1, Zagreb, 1972., str. 25-46; ista, Izvorno pravaštvo, Zagreb, 2000. Usp. komentar Mirjane Gross, Povijest pravaške ideologije, Zagreb, 1973., str. 25. Ante Starčević, Razvod istrianski od 1325., Arkiv za povjestnicu jugoslavensku, 2, Zagreb, 1852. str. 227-228. Podcrtao A. Starčević. 
triju narječja, i već je položio temelj za protivljenje Vukovoj reformi.“25 A što se tiče Starčevićeve preporuke o sakupljanju hrvatskih glagoljskih rukopisa - naišla je na relativno slab odaziv, utoliko više što u praksi glagoljica u Istri sasvim iščezava; tako je porečko-pulski biskup Antonio Peteani 1857. g. javljao goričkom nadbiskupu da u njegovoj biskupiji više nema "glagoljskog jezika“. ${ }^{26}$ Tri godine kasnije Josip Juraj Strossmayer pred Pojačanim Carevinskim vijećem u Beču (26. rujna 1860.) prigovorio je vladi „,što progoni staroslavenski jezik u crkvama Istre i Dalmacije, i u većemu dijelu Hrvatske, i što tamo meće i crkvu i hrvatski narod pod gospodstvo neslavenskog življa“27. Ipak, i poticajima kakav je bio Starčevićev bilo je prirodno da je - čim se krenulo sa slobodnijim, ustavnim periodom života u Monarhiji - jezično pitanje dođe u prvi plan zanimanja preporodnih radnika Hrvata - sada se to pokazalo - njihovo javno, prvo pokretanje jezičnog pitanja 1848. g. nije bilo samo slučajni, spontani istup već je on ležao na čvršćim premisama utemeljenim na tradicijama ilirskog pokreta, odnosno hrvatskoga narodnog pokreta $u$ hrvatskim zemljama $u$ cjelini. Uz to, pažljivije su počeli čitati zakonske propise, pa je Dobrila 1860. g. konstatirao: „Cesar dopušta, da si uzmemo što je naše, to jest: naš jezik u svih naših potribah, u ugovorih, oporukah itd. ... imamo pravo svojim jezikom se služiti po uredih, sudištih itd.“28

4.

Prvi javni sudari oko jezika dogodili su se već na prvim sjednicama prvih saziva Istarskog sabora, ${ }^{29}$ kada su se jasno konfrontirale dvije koncepcije. Jedna, talijanaško-talijanska, koja pitanje jezika i škola vidi samo kao problem obrazovnog sustava koji treba unaprijediti kako bi se mogla dobiti šira mogućnost za snaženje društvenog statusa, odnosno „društvenoga unapređenja“. Naravno, u danim povijesnim okolnostima, u kojima je apsolutno sve važne pozicije u pokrajini držao vodeći talijanaško-talijanski sloj - nije se postavljalo pitanje u čiju je korist bila usmjerena opcija za koju su bili predstavnici toga sloja. Naravno, i

25 M. Gross, Povijest, n. dj., str. 25.

26 Vjekoslav Spinčić, Slavensko bogoslužje u Istri, Pula, 1913., str. 11.

27 Biskup dr. Juraj Dobrila. Spomen-knjiga stogodišnjice njegova rođenja, Pazin, 1912., str. 91.

28 Isto, str. 232.

29 O Istarskom saboru usp. Giovanni Quarantotti, Storia della Dieta del Nessuno, Atti e memorie della Societa istriana di Archeologia e Storia patria, XLVIII (1936-1937), Poreč, 1938.; Fran Barbalić, Prvi istarski sabori (1861-1877), Rad JAZU, 300, Zagreb, 1954., str. 281-428; B. Milanović, Hrvatski, 1, n. dj.; Ivan Beuc, Pred prvo zasjedanje Istarskog sabora, Riječka revija, I, 1, Rijeka, 1952., str. 44-46. 
hrvatski su predstavnici bili za jačanje društvenog unapređenja i statusa Hrvata iz pokrajine, ali to je bilo povezano i sa željom da se upravo hrvatskim jezikom izrazi punoća hrvatske nacionalne individualnosti, i to, u početku, najviše na političkome polju. Ipak, u počecima zahtjevi su bili skromni: „Narodna prava, za koja su se zalagali tadanji predstavnici istarskih Hrvata, uglavnom su se sastojala u pravu na jezik i u dodiru s kotarskim vlastima, u pravu na hrvatske škole, pučke i srednje. ${ }^{.30}$ Nova je povijesna prijelomnica nastupila 13. travnja 1861., kada je tršćansko-koparski biskup dr. Bartolomej Jernej Legat ${ }^{31}$ kao virilni zastupnik zatražio - dakle već u samim počecima rada Istarskog sabora - da među pokrajinskim činovnicima bude netko tko poznaje i slovenski i ilirski dijalekt, jer u Istri ima Slavena koji ne poznaju talijanski jezik. ${ }^{32}$ Iako ga je podržao i krčki biskup dr. Ivan Josip Vitezić, talijanska nadmoćna većina glatko je odbila taj prvi pokušaj u Saboru da se legalizira upotreba slovenskoga i hrvatskog jezika u pokrajini. Doduše, jedan je talijanaško-talijanski poslanik (Amoroso) predlagao da se ipak imenuje barem jedan činovnik koji poznaje slavenske jezike $\mathrm{u}$ pokrajini, ali i on je isticao da službeni jezik Istarskog sabora može biti samo talijanski jezik; to posljednje prihvaćeno je kao zaključak Sabora. ${ }^{33}$ Dakle, već se tada osjetilo što može značiti prodor u saborske činovničke organe čak i samo jednoga službenika sa znanjem hrvatskog i talijanskoga jezika - mogao bi to biti početak kraja prevlasti talijanskog jezika; to je pak zadiralo u vitalne talijanaško-talijanske nacionalne i političke interese. ${ }^{34}$ Opasnost Legatova poteza odmah je uočio i nositelj istarskog iredentizma Carlo Combi, ali je u tom trenutku samo prezrivo i nadmoćno konstatirao: „Kome uputiti zapisnik na slavenskom jezi-

30 R 7979, Rukopisna ostavština Anta i Matka Rojnića, Nacionalna i sveučilišna knjižnica, Zagreb.

O B. J. Legatu usp. Gianpaolo Valdevit, Chiese e lotte nazionai: il caso di Trieste (1850-1919), Videm, 1979., str. 12 i dalje.

32 Postojale su tvrdnje da je zapravo J. Dobrila u Istarskom saboru 25. rujna 1861., na prvoj sjednici drugoga saziva, postavio pitanje upotrebe hrvatskog jezika. No, ne samo iz objavljene službene verzije saborskog zastupnika (Dieta provinciale dell'Istria in Parenzo, Puntata 4, Rovinj, 1861., str. 13 i 14) već i iz izvornika vidljivo je da je to učinio Legat (tražeži slobodnu upotrebu ilirskog i slovenskog jezika), i to 13. travnja 1861., na četvrtoj sjednici prvoga saziva Istarskog sabora, Z 1 (Spis 1), (Protocolli Dietali 1861-66), 86a)-8 i 92); vidi se da je Legatov zahtjev u zapisniku napisan na posebnom papiriću, koji je nalijepljen između str. 86a i 87; smatramo da je tekst zapravo koncept koji je napisan na brzinu: tako mu je naslov napisan olovkom, i to rukom koja nije pisala i ostali tekst, napisan tintom. Jedna je riječ - ufficio - dodana tintom, i to, čini se, trećom rukom. Alegat se sastoji od naslova i samo jedne rečenice. Cijeli je problem detaljno analiziran i objašnjen u radu Petra Strčića, Mijo Mirković i počeci hrvatskog narodnog preporoda u Istri i na Kvarnerskim otocima u XIX. stoljeću, Historijski zbornik, 25-26, Zagreb, 1972.-73., str. 416-423. Atti della Dieta, 13. 4. 1861.; F. Barbalić, Prvi istarski, n. dj., str. 295. 
ku? Čitaonicama kopača i kozara? Selima, gdje je čitanje tako strano? U kojemu od 13 slavenskih dijalekata koji se ovdje govore, treba prevoditi? Istarski Slaveni nemaju nikakvih obiteljskih ni interesnih veza sa Slavenima preko brda. ${ }^{\prime 35}$ Međutim, hrvatski su zastupnici nastavili s ofenzivnim akcijama ističući da su Slaveni većina pučanstva u pokrajini, pa više ne prigovaraju samo stoga što se saborski zapisnik vodi isključivo na talijanskom jeziku već traže da i sam Sabor s većinom, tj. sa Slavenima iz pokrajine, kontaktira na njihovu jeziku; zahtijeva se i da se zapisnici objavljuju na talijanskom i slavenskom jeziku u službenom listu Osservatore Triestino. Naravno, ti su pokušaji završili neuspjehom, iako je i poneki talijanaško-talijanski zastupnik bio svjestan da postoje i čisto slavenske općine u Istri, u kojima je nepoznat talijanski jezik, ${ }^{36}$ čime se javno demantiraju tvrdnje drugih iredentista da je talijanski zahvatio cijelu Istru.

U međuvremenu borba za jezik živo se nastavljala u Istarskom saboru. Jedna od takvih velikih i znamenitih bitaka održala se 1863. godine. Naime, u diskusiji o potrebi da se saborski govori i rasprave započnu stenografirati, Dobrila je smatrao da se oni trebaju i objavljivati te je postavio pitanje - na kojim jezicima. Podržao ga je hrvatski zastupnik Mate Jurinac ${ }^{37}$ direktno predloživši saborski zaključak - da se i zapisnici i zakoni objavljuju i na talijanskome i na slavenskome jeziku. Prijedlog su poduprli biskupi I. J. Vitezić i J. Dobrila te Talijan Favento, ali ostali su se suprotstavili. ${ }^{38}$ Zanimljiva je argumentacija s kojom su hrvatski zastupnici istupali. Tako je Jurinac svoj prijedlog obrazlagao potrebom da talijanski i slavenski element moraju izaći ususret jedan drugome kako bi to bilo korisno i za unapređivanje dobra domovine; ujedinjeni u slozi i uzajamnom poštovanju, jedan prema drugome moraju priznati recipročna prava i tako izvršavati dužnosti. M. Jurinac dakle ide s općim pogledima na ljudsku ravnopravnost, što u neprijateljski nastrojenoj većini nikako nije moglo naći odjeka. Nadalje, upozorava na istovjetnost situacije u Goričkoj i Dalmaciji ${ }^{39}$ gdje je stanje

35 Berislav Lukić, Borba za ravnopravnost hrvatskog jezika u Istarskom saboru, Jadranski zbornik, 2, Rijeka - Pula, 1957., str. 123.

36 Atti della Dieta, 15. 4. 1863.; F. Barbalić, Prvi istarski, n. dj., str. 295-296.

37 Agneza Szabo, Matija Jurinac iz Kastva - političar i dobrotvor, Zbornik Kastavštine, 21, Kastav, 2017., str. 225-240.

38 Ati della Dieta, 13. 1. 1863.; F. Barbalić, Prvi istarski, n. dj., str. 325-327. Usp. i komentare Mije Mirkovića, O smislu i sadržaju narodnog preporoda u Istri, u: Hrvatski narodni preporod u Dalmaciji i Istri, Zagreb, 1969., str. 15-16; B. Lukić, Borba, n. dj., str. 123; B. Milanović, Hrvatski, 1, n. dj., str. 229-231.

39 Usp. Vjekoslav Maštrović, Jezično pitanje u doba narodnog preporoda u Dalmaciji, u: Hrvatski narodni preporod u Dalmaciji i Istri. Zbornik, Zagreb, 1969., str. 219-242. 
- po njemu - drukčije i gdje se dva elementa „poštuju uzajamno i priznaju doista recipročna prava“. ${ }^{40}$ Osobito je važna Dobrilina intervencija kojom je podržao Jurinčev prijedlog. Dobrila se najprije ogradio od mogućih primjedaba da je pristran istaknuvši da je on pastir i Talijana i Slavena, da mu ne može netko bilo čime pokazati da je učinio krivo Talijanima. Zatim upozorava na činjenicu da su Slaveni u Istri već 1.200 godina, da su bili i pod Rimljanima, a da su još uvijek ostali Slaveni. Za Dobrilu je to važan dokaz da je zapravo nemoguće promijeniti njihovu narodnost i jezik. Zatim biskup prelazi na praktične stvari. Naprimjer, u Poreču djeluju talijanske škole, uredi, institucije, ali kakva je od njih korist i dobro za Slavene - pita se biskup. Sve ono što je pomoglo Talijanima da se uzdignu treba sada učiniti i Slavenima, ali ne drugim, već njihovim vlastitim jezikom. Podsjeća na prošla vremena kada je dominirao njemački jezik, pa su se zbog toga jako tužili Talijani. A - zar se „hoće sada upotrebiti sila da se nametne talijanski jezik?". Tada nabraja primjere pravednosti i tolerantnosti - u Češkoj Nijemci i Česi uče jezike jedni od drugih, u Tirolu je omogućeno da Nijemci i Talijani imaju posebne škole, vladin komesar u saboru u Pragu govori i na češkom jeziku, u Šleskoj je usvojeno da se zapisnici vode na poljskom, češkom i njemačkom jezi$\mathrm{ku}, \mathrm{u}$ Gorici se spisi rješavaju na talijanskom, slovenskom i njemačkom jeziku, a narodnosna osobitost uzima se u obzir i u Dalmaciji i Moravskoj. Dobrila, uz to, stalno apelira na pravednost talijanskog elementa i zastupnika, ali izriče i čuvene dvije prijeteće rečenice: „Slavenski narod spava, ali tko spava nije umro. Tko spava može se probuditi i kad se probudi, mogao bi to učiniti na način, koji bi bio možda nezgodan za talijanski element." Razvila se diskusija, u kojoj je zastupnik Giuseppe Parisini istaknuo da bi Slaveni zaista imali pravo dobivati štampane službene tekstove na svojem jeziku, samo je problem u kojemu - u slovenskom ili srpskom. ${ }^{41}$ Međutim, narod ne razumije te jezike jer govori razna narječja ${ }^{42}$ te, štoviše, Slaveni ne znaju ni čitati ni pisati, ali zato više razumiju talijanski jezik. Bilo je to u punom skladu s iredentističkim mislima, prema kojima u Istri nema

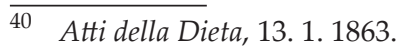

41 Nije, za sada, jasno što je zapravo 1869. g. mislio riječki gimnazijalac kad je u svojem dnevniku komentirao riječi riječkoga velikog župana Bartola Zmajića: „Prv. Gospodin kaza, da on nije za ono, što nekoji brboću, sve naše ostavit, pa se Rusom podati. Bogme nisam ni ja zato. Da mi idemo ostavit naš lipi bogati jezik - za rusku literaturu. To ne, jer onda bismo sami sebi čitali a ne puku." NSK (Nacionalna i sveučilišna knjižnica Zagreb), DML, R 6261, 16. 10. 1869.).

42 Zanimljivo je da je i Milorad Ekmečić u knjizi Istorija Jugoslavije, Beograd, 1972., str. 271, prihvatio talijanaško-talijanska mišljenja o dijalektima. Usp. i Petar Strčić, Primjedbe na tekst o Istri u drugoj polovici XIX. st. u 'Prosvetinoj' Istoriji Jugoslavije, Časopis za suvremenu povijest, V, 1, Zagreb, 1973., str. 198-200. 
Hrvata, a Slaveni su u njoj necivilizirane i nekulturne pridošlice. Dobrila je po prirodi bio nagao, ${ }^{43}$ pa je odmah, relativno grubo, odgovorio nadmenom Parisiniju pogađajući ga u živac; Dobrila, jednostavno, Parisinija proglašava običnom neznalicom što se tiče jezika Slavena u Istri, jer nikada nije pročitao nijedne slavenske knjige, a kamoli da bi mogao sklanjati ijedno slavensko ime. Direktno mu je odbrusio: „Ne možete o predmetu govoriti.“ Zatim ga je upozorio na činjenicu da i Talijani u pokrajini govore raznim narječjima, pa tako oni u Puli ne govore kao oni u Vodnjanu, a u Rovinju kao oni u Poreču, i drugdje; međutim, Dobrila podsjeća: ipak je samo jedan pismeni talijanski jezik koji, naravno, svi razumiju. Isti je slučaj i sa slavenskim jezikom, a kao dokaz biskup iznosi primjer crkvene liturgije: slavenska knjiga Evanđelje upotrebljava se u cijeloj pokrajini, dakle u cijeloj Istri i na Kvarnerskim otocima; štoviše, to je slučaj s istom knjigom „,i u najudaljenijim slavenskim zemljama, čak u Bosni i na granicama Ugarske“. Naravno, Dobrila je svjestan situacije, opet apelira na pravednost; zna da će Jurinčev i njegov prijedlog biti odbijen, ali ipak traži glasanje.

Godinu dana kasnije Zemaljski odbor krenuo je u akciju kojom je želio potvrditi stanje u pogledu jezika u školama ${ }^{44}$ ističući da obuka mora biti samo talijanska, jer je i kultura samo jedna, također talijanska; a ništa se ne bi postiglo ako bi se pokušalo udariti temelje i drugoj kulturi. Uostalom, sve općine ionako zahtijevaju da nastava bude samo na talijanskome jeziku. Zato se u Saboru predlaže, između ostalog, da u talijanskim gradićima i mjestima pučke škole budu na talijanskom, a u slavenskim mjestima slavenske, ali s time da se ovdje podučava i talijanskome jeziku, koji bi Slavenima koristio. U koparskoj gimnaziji nastavni jezik neka bude talijanski, njemački obavezan, a samo za stipendirane učenike neka bude obvezan i slavenski jezik. Odmah je istupio Dobrila otvoreno prigovarajući prozirnoj tendenciji toga prijedloga o nastavnom jeziku - da se Slaveni potalijanče. Dobrila nema ništa protiv toga što Slaveni uče i druge jezike, oni se i ponose njihovim znanjem, ali oni traže nešto više od toga - oni žele puno poštovanje svoje narodnosti, a to se ne čini iznesenim prijedlogom pokrajinske vlade. U pokrajini žive dvije narodnosti, s dva jezika, i „ako hoćemo imati naših svećenika, sudaca, odvjetnika, liječnika, potrebno je da oni jednako poznaju

$\overline{43}$ „Ni mučati ne umijem ili ne mogu, kad treba. Veliko je zlo što se izlivam van sebe kao vjetar, nepazeć na ono, što se radja u srcu i u pameti... Ja lahko vjerujem prvom utisku i odkrijem, što mi je na srcu na škodu dobrojsvrsi, za kojom idem." Matko Mandić, Tri pisma biskupa Dobrile, Veliki Ćiril-Metodski kalendar za 1907, I, Zagreb, str. 14.

44 O pojedinim važećim državnim i provincijskim (za Austrijsko primorje) školskim propisima i uputama na početku 60-ih godina usp. Il ricoglitore Triestino, I, 1863., str. 113-140, II, 1864., str. 99-131. 
jezik slavenski i talijanski, jer samo tako mogu služiti obje narodnosti“. U daljnjoj diskusiji Dobrila je učinio neposredan prijedlog: da pučke škole u slavenskim mjestima imaju slavenski nastavni jezik, a samo prema potrebi talijanski i njemački. ${ }^{45}$ Borba za jezik nastavljala se jer je ona označavala i nastojanje da se postigne i kulturna i politička ravnopravnost te da se spriječi denacionalizacija hrvatskog življa, koja je bila u tijeku. U tome smislu treba shvatiti i nastojanje da se stipendije ne daju samo onima koji polaze gimnaziju u Istri već i onima koji se školuju u hrvatskim školama Rijeke i Senja, kamo idu učenici s otoka Krka, iako se to opravdavalo samo činjenicom da su im ta susjedna kopnena mjesta bliža. ${ }^{46}$ Biskup Dobrila rješavao je to - ako je to bilo u njegovoj biskupskoj moći - i sam, osobno, iz svojih biskupijskih sredstava ili namjenskih sredstava namjesništva u Trstu. I dok je njegov prethodnik Peteani redovito dodjeljivao stipendije onima koji su se školovali u talijanskim školama u Videmu (Udine) i u mjestu Chioggia, a povremeno i onima u Kopru i Pazinu ${ }^{47}$ čime je - u slučaju hrvatske djece poticao potalijančivanje, Dobrila je učenike slao u Kopar i Pazin, gdje su mu bili pod bližom kontrolom, ili u Rijeku i Senj, gdje su se odgajali u hrvatskom duhu. ${ }^{48}$ Jer: „Redke su to prilike da dobija zemaljski djak, koji je na hrvat. gimnaziji“ bilježi gimnazijalac M. Laginja u povodu jednog slučaja 1869. godine, pa zbog toga „valja biti zaklet neprijatelj danas sutra, onim našim krvopijam. ${ }^{\prime \prime 4}$ No, to je nosilo sa sobom drugu opasnost - da se završeni srednjoškolci i studenti ne vrate u Istru, jer se od 1869. g. provjeravalo stečeno znanje u neaustrijskim zemljama i nisu se priznavale svjedodžbe - o čemu je uzalud u parlamentu 1874. g. interpelirao D. Vitezić. ${ }^{50}$ Pitanje nastavnog jezika nije silazilo s dnevnog reda Sabora, jer je to bilo vitalno pitanje i talijanaško-talijanskog i hrvatskog preporodnog pokreta u cjelini, pa je Dobrila naprimjer oštro inzistirao na tome da se slavenski jezik u koparsku gimnaziju uvede kao obvezatan, a ne samo za neke učenike. Doduše, još 1852. g. to je bilo i određeno, ali je uvedeno tek deset godina

$\overline{45}$ Atti della Dieta, 18. 4. 1863; F. Barbalić, Prvi istarski, n. dj., str. 334-336.

46 Isto, 9. 3. 1863.; F. Barbalić, Prvi istarski, n. dj., str. 331.

47 APPB (Arhiv Porečko-puljske biskupije, Poreč) , sv. X/L, 1815-1874, br. 683, 1857, br. 713, 15.7. 1857.; B. Milanović, Hrvatski, 1, n. dj., str. 240.

48 APPB, sv. X/1, 1815-1874, br. 92, 10. 4. 1863., br. 342, 27. 4. 1863., br. 7, 14. 2. 1864. Usp. i NSK, DML, R 6261, 25. 2. 1869. Usp i u APPB br. 81 (biskupijski br. 505), Antun Mažuranić - J. Dobrili, Rijeka, 20. 4. 1864., te br. 342, J. Dobrila - A. Mažuraniću, Poreč, 27. 4. 1862. Sličnih dopisa ima dosta u APPB. Usp. i B. Milanović, Hrvatski, 1, n. dj., str. 239-240. NSK, DML, R 6261, 25. 2. 1869.

50 Dinko Vitezić, Poslanica kojom obaviešćuje svoje birače o svojem zastupničkom djelovanju u zadnjih dvih saborskih razdobjih, Trst, 1885., str. 7-10. 
kasnije, i to tek djelomice. Međutim, koparska gimnazija bila je jedina u pokrajini i jasno je koliko je ta činjenica utjecala na odgoj i obrazovanje istarske mladeži $\mathrm{u}$ talijanskom duhu. Dobrila ponovno u Saboru ističe činjenicu da se u pokrajini upotrebljavaju talijanski i slavenski jezik, a ovaj pogotovo na selu; potrebno je da svi službenici - te svećenici, odvjetnici, suci, liječnici - poznaju oba jezika, jer jedino će tako udovoljiti svojoj dužnosti te vladinu zahtjevu „da svaki činovnik mora znati slavenski jezik". U suprotnom dolazi do štete za slavenski svijet, pa iznosi i primjere, ${ }^{51}$ od kojih se jedan - spomenut već prije - odnosi neposredno na njega, kako u kasnijim godinama otkriva upravo iredentistički prvak De Franceschi. ${ }^{52}$ Dobrila je čak predlagao da se u koparskoj gimnaziji smanji broj nastavnih sati grčkoga jezika i nekih drugih predmeta, a u korist slavenskog jezika. Štoviše, predložio je još jednu radikalnu mjeru - da se niža njemačka gimnazija u Pazinu ${ }^{53}$ pretvori u višu obrazovnu instituciju, s time da se u svim njezinim razredima poučava slavenski jezik..$^{54}$

U toj borbi, naravno, nisu se birala sredstva, širile su se i dezinformacije, pa i to da učitelji u seoskim školama i ne znaju talijanski već samo slavenski jezik. To je Dobrila u samome Saboru demantirao ističući da je situacija upravo obratna, tj. da učitelji i svećenici znaju samo talijanski jezik, pa uopće ne mogu podučavati slavensku djecu. To se, doduše, čini pod zgodnim izgovorom - da je talijanski jezik Slavenima potreban radi trgovine. Međutim, Dobrila otkriva da nije samo u pitanju očit sustavni rad na denacionalizaciji najmlađih pripadnika hrvatskog naroda već da se radi i o općem problemu u pokrajini - nedostaje i učitelja i školskih zgrada, „pa se u najviše slučajeva ne može uopće podučavati ni u jednom jeziku“ ${ }^{\prime 55}$. Ali, zato je postojala brojna školska literatura na talijanskom jeziku; za školsku djecu u Primorju u početku 60-ih godina knjige su uglavnom

51 Atti della Dieta, 20. 4. 1864.; F. Barbalić, Prvi istarski, n. dj., str. 336-337.

52 C. De Franceschi, Memorie, n. dj., str. 193; isti, Uspomene, n. dj., str. 165.

53500 godina franjevačkog samostana u Pazinu. 1481.-1981., Pazin, str. 20-23.

54 Atti della Dieta, 20. 4. 1864.; F. Barbalić, Prvi istarski, n. dj., str. 337.

55 Atti della Dieta, 2. 12. 1865.; F. Barbalić, Prvi istarski, n. dj., str. 338. - Godine 1862. na području Porečko-puljske biskupije bilo je 37 škola s 82 člana školskog osoblja te 2.401 učenikom; na području Krčke biskupije bilo je 46 škola s 98 članova školskog osoblja i 4.968 učenika. Na otocima Krku, Lošinju i Cresu bila je po jedna glavna škola (osnovna). Na području Porečko-puljske biskupije bila je po jedna u Poreču, Rovinju i Puli; na području Tršćansko-koparske biskupije bila je po jedana u Kastvu, Pazinu, Kopru i Piranu (i 6 u Trstu). Popise imena nadležnih školskih dužnosnika, nastavnika i učitelja te mjesta u kojima su se škole nalazile (po biskupijama) na početku 60-ih godina 19. st. usp.: Scematismo delle scuole reali i popoplari nella Provincia del Litorale, Il Ricoglitore Triestino, I, 1863., str. 152-180; Scematismo di tutte scuole nella Provincia del Litorale, isto, II, 1864., str. 132-184. 
dopremane iz sjeverne Italije, ali se mnogo radova štampalo i u Trstu. Takve (talijanske) literature bilo je toliko da se mogla razvrstati i po područjima, npr. Libri di lettura; Gramatiche e ortografie; Arte del comporre; Epistolari; Declamazione; Lingue; Dizionari; Caligrafia, stenografia e disegno; Architettura; Geografia e storia; Storia naturale; Matematica; Fisica; Meccanica; Pedagogica; Educazione; Opere religiose. Međutim, $\mathrm{u}$ izdanjima se ne spominje nijedno na hrvatskome (i slovenskome) jeziku. ${ }^{56}$

\section{5.}

Situacija se dakle nije popravljala; ${ }^{57}$ Dobrila je ovako 1869. g. pisao Baltazaru Bogišiću: „Ah, moj dragi Gospodine! Mi ovdje pogibamo. Ko nas nije mogao na svoju pretvoriti, taj nas je sad bacio u ždrijelo svojega i našega dušmanina. ${ }^{58}$ Nas ima dvie trećine i veće; osnovali su u Rovinju (... $)^{59}$ sasvim italijanski; školski savjetnici su malo ne svi Italijani, koji niti naš jezik znadu niti zanj mare, paše oni nanj mrze. Školskoga nadzornika nemamo još; ovdje govore, da ga ni netreba, jer se straše da ko ne dodje, viešt i našem jeziku. Kod okružnoga suda (i kriminalnog) u Rovinju još je tumač neki bačvar. (...) Sad nagovaraju prosti i bezazleni narod evo ovako: Šta ćete vi sa svojim hrvatskim jezikom? Ta vi nemožete ni sa sudci i poglavari (činovnici); tražite dakle svi jednoglasno, da vam djeca po selih uče samo italijanski; nenaučite li italijanski jezik, to će doći rus, pa će nam pogaziti i jezik i vjeru. ${ }^{\prime 60}$ Tako je naprimjer 1879. g. nova krčka općina (južni i jugozapadni dio otoka Krka), koja ima 5.100 „Slovinacah“ i 1.700 Talijana, donijela odluku da se ukida hrvatski nastavni jezik u školama, a uvodi talijanski, a jedino će se vjeronauk ipak predavati na hrvatskom jeziku. ${ }^{61}$ Sličan slučaj istodobno se događa i u Osoru i Nerezinama na otoku Cresu. ${ }^{62}$ Naša sloga uzalud se pozivala na primjer Istarskog razvoda, ${ }^{63}$ te na nonsens da Pula ima 15.000

\footnotetext{
56 Bibliografia scolastica, u: Il Ricoglitore Triestino, annuario pedagogico per 1863 col Almano 1863, I, str. 17-152.

57 Dragovan Šepić, u: Jaroslav Šidak, Mirjana Gross, Igor Karaman, Dragovan Šepić, Povijest hrvatskog naroda 1860-1914, Zagreb, 1968., str. 62-63.

58 Dobrila vjerojatno - u prvom slučaju - misli na Austrijance, a u drugome na talijanaško-talijanske protivnike.

59 Oštećen papir.

60 Ante Marinović, Neobjavljeno pismo biskupa Dobrile Dru Baldu Bogišiću, Riječka revija, I, 3, Rijeka, 1952., str. 166.

61 Naša sloga, I, 4, Trst, 16. 7. 1870.

62 Isto, 5, 1. 8. 1870.

63 Isto, 6, 16. 8. 1870.
} 
stanovnika, jednu njemačku i jednu talijansku školu, a nijednu na hrvatskom jeziku. ${ }^{64}$ Konačno, došlo se i do sudske presude - sudac krčkoga kotarskog suda Wurmbrand presudio je u sporu između Ivana Rafaela Dujmovića iz Bašćanske Drage i Domenica de Dessantischa iz Baške da se u objema Baškama ne govori hrvatskim već slaveno-ilirskim jezikom koji je sličan slaveno-dalmatinskom jeziku, pa se i štampaju posebne ilirske i posebne hrvatske slovnice, i to kako bi se ujedinili jezici i stvori srpsko-hrvatski jezik. ${ }^{65}$ Uzalud su otočani javno protestirali: „Kod nas na Otocih i ostaloj Istri ne zna ni dijete drugač odgovoriti, nego da je Hrvat i da govori Hrvatski";"66 prizivni sud ipak je u Trstu potvrdio presudu. ${ }^{67}$ Doduše, velika podrška u borbi za materinski jezik i kroz njega za nacionalnu samobitnost došla je u vezi sa slučajem veoma popularnog pomorskog kapetana Petra Lusine, koji je bio član ekspedicije brodom Tagetthoff 1872. - 1874. g. na Sjevernom polu; naime, Lusina je dopisniku tršćanskog lista Adria izjavio da nije Talijan, kako ga se proglašava, već Slaven, ima slavensko ime, a roditelji su s njime govorili slavenskim jezikom. ${ }^{68}$ Talijanaško-talijanske vladajuće strukture, međutim, od šestog desetljeća općenito su u ofenzivi koristeći se pri tome i uzastopnim većim vanjskopolitičkim i unutarnjopolitičkim teškoćama u koje je upadala Monarhija ${ }^{69}$ Temperatura 60 -ih godina intenzivno raste - onako kako se Apeninski poluotok ujedinjuje, Habsburška Monarhija povlači, upada u krizu i pretvara u Austro-Ugarsku i kako je u Istarskom saboru sve očitije da se ne može na kraj izaći s hrvatskim i slovenskim predstavnicima, iako su - čak - i sasvim malobrojni. Stiže se i do postavljanja tvrdnje da je samo jezik bitan u opredjeljivanju za narodnost, a budući da je talijanski jezik apsolutno prevladavajući, onda stanovništvo i austrijskog i dalmatinskog primorja zapravo sada čine samo Talijani (bez obzira na očitu slavensku prošlost nekih skupina). ${ }^{70}$ Koristeći se primjerice ishodom rata 1866. g. na Apeninskom poluotoku, kada je Austrijska Carevina izgubila Veneciju u korist Kraljevine Italije, Zemaljski je sabor Istre zadnjih dana te godine odobrio peticiju Zemaljskog odbora samome vladaru, $\mathrm{u}$

\footnotetext{
64 Isto, II, 1, 1. 1. 1871.

65 Isto, $\mathrm{V}, 1,1.1 .1874$.

66 Isto, 3, 16. 2, 8. i 16. 4. 1874.

67 Fran Barbalić, Narodna borba u Istri od 1870. do 1915. godine. Prema bilješkama iz "Naše sloge", Zagreb, 1952., str. 34.

68 Radojica F. Barbalić, Pomorska problematika u 'Našoj slogi', Pazinski memorijal, 1, Pazin, 1971., str. 68-69.

69 Alan John Persival Taylor, Habsburška Monarhija 1809-1918, Zagreb, 1990., str. 113 i dalje.

70 Gaspare Bonicelli, Storia dell'isola deo Lossini. Con appendice, Trst, 1869., str. 27, 55-56, 65 i dr.
} 
kojoj je zatražio otvaranje više škole za pokrajine Istru, Južni Tirol, Dalmaciju, Trst i Goricu; naglasak je bio na tome da se otvori u bilo kojem od talijanskih gradova Austrije. Razlog je tome zahtjevu gubitak austrijskih pokrajina na Apeninskom poluotoku i nemogućnost studiranja na talijanskom jeziku; u navedenim pokrajinama Monarhije ima oko 1.400 .000 stanovnika, doduše od toga je više Slavena, ali oni imaju talijansko obrazovanje, a zbog veza s Kraljevinom Italijom sve više usvajaju talijanski jezik. Vlada je, međutim, odbila taj zahtjev, ali je dozvolila talijanski kao nastavni jezik u gimnaziji u Kopru. ${ }^{71}$ Štoviše, u toj je gimnaziji 1868. g. ukinut slavenski jezik za talijanske stipendiste, ${ }^{72}$ a na ruku odnarođivanja išao je i prelazak škola iz crkvenih u državne ruke 1869. godine, pa se broj hrvatskih naglo smanjio, a pokrajinski se organi, jasno, nisu pobrinuli da svećenicima nađu adekvatnu zamjenu. ${ }^{73}$

Osiljeni talijanaško-talijanski sloj krenuo je u novu ofenzivu u pogledu jezika; naime, Zemaljski je odbor 20. rujna 1867. poslao predstavniku Ministarstva unutarnjih poslova: „U predstavci se napominje, da Pokrajina Istra priznaje samo jedan kulturni jezik, a to je talijanski; da je ovaj jezik njeni odgojni jezik kroz šest stoljeća i da su pisali i stjecali slavu u književnosti i nauci ovim jezikom mnogi između njenih najslavnijih sinova; da je to jezik služenja i svih trgovačkih transakcija i pripada svakom Istraninu, koji teži za kulturom. U predstavci je traženo, da se zbog svih ovih razloga uvede i čuva talijanski građanski element kulturniji i civiliziraniji, sav predan naprednoj obradi zemlje, industriji i trgovini, dok je slavenski elemenat izmiješan, manje napredan i radin, zemljoradnički i pastirski. U predstavci se još predlaže, da općine budu mjerodavne u određivanju jezika u općinskim školama, jer su inače općine bile velikim dijelom u rukama talijanskim zahvaljujući izbornom cenzusu, koji je garantirao politička prava ekonomski jačim društvenim slojevima.. ${ }^{174} \mathrm{U}$ međuvremenu vladajućem sloju idu na ruku i izmjene u organizaciji školskog sustava. Naime, čl. 19. austrijskog ustavnog zakona od 21. prosinca 1867. određivao je: „U zemljama, u kojima žive različite narodnosti, moraju biti zavodi za opću naobrazbu tako uređeni, da svaka od tih narodnosti nađe sredstava, da se može naobraziti u svojem jeziku, a ne treba da budu primorana učiti koji drugi jezik Pokrajine. ${ }^{\prime \prime 75}$ No, dvije godine

\footnotetext{
71 B. Lukić, Borba, n. dj., str. 124-125.

72 F. Barbalić, Prvi istarski, n. dj., str. 412.

73 Mate Demarin, Hrvatsko školstvo u Istri. Pregled razvoja 1818-1918, Zagreb, 1978., str. 33 i dalje.

74 B. Lukić, Borba, n. dj., str. 124.

75 Dinko Vitezić, Druga poslanica kojom obavješćuje svoje birače o svojem zastupničkom djelovanju u saborskom razdoblju 1885. do 1891., Trst, 1891., str. 5.
} 
kasnije donesen je državni školski zakon (14. svibnja 1869.), čiji je čl. 6 precizirao da ,o nastavnom jeziku i o poučavanju u drugom zemaljskom jeziku odlučuje u granicama, koje određuje zakon, Pokrajinsko školsko vijeće, nakon što presluša one, koji uzdržavaju škole. ${ }^{\text {"76 }}$ Time je, zapravo, školstvo došlo u ruke pokrajinskih organa, što je u Istri imalo veoma loše posljedice i za školski sustav i za nastavni jezik većine pučanstva. Na sve to došao je i prekid dotadašnje organizacije školovanja; naime, prema konkordatu između države i crkve od 1855. godine, škole su bile i u crkvenoj nadležnosti; ${ }^{77}$ do tada su u školama poučavali svećenici, a sada su umjesto "trivijalne“ škole i „normalke“ uvedene „opća pučka“ i „građanska" škola; time je prestao važiti konkordat između države i crkve. ${ }^{78}$ Godine 1870. donesena je uredba da se u prijelaznom roku od dvije godine i svećenićke pomoćne škole pretvore u svjetovne, ${ }^{79}$ a od 1872. g. učitelje imenuje pokrajinska uprava u Poreču. ${ }^{80}$ Dakle, cijeli je školski sustav od tada pod punom kontrolom vladajućega talijanaško-talijanskog sloja u Istri i na otocima. S obzirom na to da su u to doba svećenici bili gotovo jedini nosioci preporodnog pokreta, nova organizacija školskog sustava značila je pravu katastrofu za hrvatski i slovenski narod. S obzirom na to da svećenici nisu smjeli podučavati, a hrvatskih i slovenskih učitelja nije bilo, dogodilo se da je samo u tršćanskom području odjednom bilo zatvoreno četrdeset hrvatskih i slovenskih škola. ${ }^{81}$ Vladajuće strukture nisu bile zainteresirane za hrvatsko školstvo - g. 1872. u središnjoj Istri, u pazinskom kotaru primjerice, radile su samo talijanske osnovne škole - naglije opada broj hrvatskih škola i učenika; situacija se pogoršavala sljedećih godina ${ }^{82}$ Tako je već sljedeće, 1870. g. broj hrvatskih i slovenskih učenika pao s 5.026 na 3.950; ako se ima u vidu da je u Istri školu pohađalo svega 370 obveznika, ${ }^{83}$ onda je situacija jasna, jer to je bilo nauštrb hrvatskih i (slovenskih) polaznika osnovnih škola, koji su pretežno stanovnici sela i zaselaka. ${ }^{84}$

\footnotetext{
76 Isto, str. 9.

77 Dragutin Franković, Povijest školstva i pedagogije u Hrvatskoj, Zagreb, 1958., str. 11.

78 Domenico Venturini, Squardo sommario sullo sviluppo della scuola popolare in Istria nel secolo XIX, Poreč, 1901., str. 15.

79 Naša sloga, XVII, Trst, 16. 10. 1881.; D. Vitezić, Druga poslanica, n. dj., str. 20.

80 Naša sloga, III, Trst, 1. 12. 1872.

81 Božo Milanović, Biskup Dobrila i njegovo doba (1861-1882), u: Hrvatski narodni preporod u Dalmaciji i Istri. Zbornik, Zagreb, 1969., str. 385.

82 Isto, str. 386.

83 D. Franković, Povijest, n. dj., str. 148.

84 Tone Peruško, Borba za osnovno školstvo - borba za nacionalni opstanak, u: Hrvatski narodni preporod u Dalmaciji i Istri. Zbornik, Zagreb, 1969., str. 426.
} 
U tome se smjeru kretala i akcija da se franjevačka njemačka niža gimnazija u Pazinu sekularizira i pretvori u talijansku, što je preraslo i u velik pokrajinski spor; u njega se umiješalo i tršćansko namjesništvo, koje je smatralo da u Pazinu treba ostaviti njemački i uvesti slavenski jezik, te Carevinsko vijeće, gdje su slavenski zastupnici zatražili slavenski jezik za pazinsku gimnaziju. Taj zahtjev podržale su trideset i dvije istarsko-otočne općine, među njima i Hrastovlje, Dolina, Materija, Kastav, Peroj itd. u Istri, te Omišalj, Dobrinj i Vrbnik na otoku Krku. ${ }^{85} \mathrm{Na}$ to je uslijedila žestoka protuofenziva - od 138 općina u pokrajini, njih 106 izjasnilo se za talijanski jezik, pa je Zemaljski odbor naglasio da su slavenske peticije "skoro sve iz sela najniže kulture“ te, štoviše: "gdje je župnik stranac i Slaven "86. Talijanaško-talijanski zastupnici u parlamentu Francesco Vidulich i Orazio Colombani dobili su instrukcije s veoma radikalnim rješenjima: ako gimnazija u Pazinu ne može biti talijanska, onda neka ostane samo njemačka; ali ako se u vladinim krugovima ipak bude išlo na to da se škola organizira kao talijansko-slavenska jezična škola, onda je bolje da se ukine! ${ }^{87}$ Vladajuće strukture i kasnije nisu odustajale od pokušaja da se pazinska gimnazija ipak pretvori samo u talijansku, hrvatska saborska manjina dokazivala je da je Pazinština hrvatska, talijanska većina privremeno se povlačila predlažući da slavenski jezik bude fakultativan, što je $\mathrm{u}$ praksi značilo da neće biti ni nastavnika ni učenika. Bečka je vlada međutim odlučila drukčije - da se škola na pokrajinski račun organizira kao viša gimnazija, ali samo na njemačkom jeziku, što je saborska većina odbijala tražeći talijanski nastavni jezik. ${ }^{88}$

U sve to umiješali su se 1873. g. i veoma aktivni hrvatski preporodni zastupnici u Saboru, pa je Antun Spinčić izjavio kako on ne želi ni jednu ni drugu jer dvije trećine slavenskog pučanstva nema nijedne: „To nije jednakost, a ne odgovara ni državnom temeljnom zakonu, koji osigurava svakoj narodnosti jezik u školama i uredima. Neka vlada naloži činovništvu da nauči jezik naroda i da ga upotrebljava s narodom.“ On je naglasio kao „apsurd, što se u drugoj polovici 19. vijeka upotrebljavaju u tribunalu tumači: bačvari i postolari“. Upozorava i na materijalnu stranu pitanja - ta Slaveni iz Istre snose jednake, ako ne i veće, financijske terete u pokrajini, a kako su ih dvije trećine, morali bi imati i jednaka prava. Zato u Pazinu ili drugdje treba biti gimnazija na slavenskom jeziku. Tali-

\footnotetext{
85 F. Barbalić, Prvi istarski, n. dj., str. 357.

86 B. Lukić, Borba, n. dj., str. 125.

87 F. Barbalić, Prvi istarski, n. dj., str. 357.

88 Isto, str. 380; B. Lukić, Borba, n. dj., str. 128.
} 
janaško-talijanska većina odgovarala je protupitanjem o više slavenskih dijalekata u Istri, na što je A. Spinčić parirao tvrdnjom da u cijeloj Istri ima samo jedan dijalekat - pri tome je očito mislio na hrvatski jezik, jer je dodao da se samo u koparskom kotaru govori slovenski; kao ranije Dobrila, sad i on spominje primjer čitanja Evanđelja u crkvi, koji je na istome jeziku i svi ga razumiju. I onda je taj Kastavac, župnik u Mošćenicama, potegnuo vrlo uvjerljiv argument: „Vi velite, da nemamo jezika, a ja vam velim, da mi već imamo više gimnazija, u kojima je nastavni jezik slavenski, da imamo i već i sveučilište nedavno otvoreno sa 4 fakulteta." Misleći pri tome na gimnazije u ostaloj Hrvatskoj i na Sveučilište u Zagrebu, Spinčić se jasno deklarirao kao Hrvat, kao pripadnik naroda kojemu je matica izvan Istre. Krčki zastupnik Petar Žic slikovito je izrazio svoje protivljenje vladinoj odluci da pazinska gimnazija bude njemačka: ako bi netko otvorio gimnaziju s talijanskim jezikom u Gornjoj Austriji - zatvorili bi ga u ludnicu. Ali, Slavenima je potrebna gimnazija, pa je predložio da se otvori na $\mathrm{Krku}^{89}$ te je u tome smislu 1874. g. i službeno podnesen zahtjev ministru nastave; no, zahtjev je odmah odbijen, a odobreno je (samo) deset stipendija za učenike svih Kvarnerskih otoka, ${ }^{90}$ ali i to pod uvjetom da polaze njemačku gimnaziju u Pazinu. ${ }^{91}$ Inače, $u$ pokrajini su tada radile talijanska gimnazija $u$ Kopru, realka u Piranu i nautička škola u Lošinju te njemačka gimnazija u Pazinu i niža realka u Puli. ${ }^{2}$ A gotovo u svim pučkim školama nastavni je jezik talijanski; čak se i vjeronauk „nepodučaje hrvatskim jezikom, a ako tkogod spotrebe hrvatski štogod podučaje, proglasuje ga se 'panslavistom'“.93

Bitka je, međutim, bila bez izgleda za uspjeh i zbog stajališta same vlade; naime, dok je 1876. g. ministar bogoštovlja i nastave izjavio da Slaveni „mogu čuvati svoju narodnost, oni mogu gojiti svoj jezik, on se uvađava u uredu i školi", drugi član te iste vlade - ministar pravosuđa - izjavio je da se, što se tiče "gojenja“ jezika, ne može sa Slavenima postupati kao s Talijanima u Južnom Tirolu, jer Slaveni „,nestoje na dosta visokom kulturnom stupnju“, ${ }^{\prime \prime 4}$ što je bilo izrečeno na nivou uobičajenih iredentističkih razmišljanja. Tako je Vitezić u parlamentu

\footnotetext{
89 Atti della Dieta, 20. 12. 1873; F. Barbalić, Prvi istarski, n. dj., str. 383-384. Krčkim učenicima bila je puno bliža senjska gimnazija, pa su je i polazili. AKB (Arhiv Krčke biskupije, Krk), 1870., br. 1051, 14/15. 12. 1870.).

90 D. Vitezić, Poslanica, n. dj., str. 11-12.

91 Isto, str. 12-13.

92 Isto, str. 15.

93 Isto, str. 18

94 Isto, str. 10.
} 
i 1880. g. morao govoriti o istoj stvari, podnoseći i posebni „Memorial“. No, ništa se nije mijenjalo - prisutni talijanaško-talijanski zastupnici nisu se udostojili čak ni protestirati, ${ }^{95}$ toliko su bili sigurni u sebe. No, borba za jezik u školama nastavljala se i dalje, pa je zato dolazilo i do žestokih polemika u Istarskom saboru, u okviru kojih je osobito rječit bio Antun Spinčić. Taj je Kastavac 1880. g. istaknuo kako je prirodno da Talijani imaju više naobraženih ljudi nego Slaveni, jer su imali i znatno više mogućnosti da se školuju, ali to ne znači da Talijani zato moraju imati monopol na kulturu: „Ovo neprestano naglašavanje talijanske kulture vrijeđa moje narodno čuvstvo i želim, da se ne ponavlja tako često u ovom saboru. ${ }^{\prime 96}$ Pred malo godina nije bilo moguće ni na ulici govoriti hrvatski, kaže Spinčić, ali u zadnjih deset godina učinjeni su „gorostasni“ koraci naprijed. Svjedočenje je to i o snažnijem napretku hrvatskoga narodnog preporoda u cjelini. Razotkrivale su se i nedopustive metode jezične denacionalizacije u školskom sustavu - g. 1880. zastupnik Andrija Šterk ${ }^{97}$ upozorio je da se do 1870. g. nastojalo podučavati u školama na istom jeziku kojim se govorilo i u crkvi, a od tada se u školama napušta slavenski jezik. ${ }^{98}$ Godinu dana kasnije Šterk je zatražio da se u pazinskoj gimnaziji predaje i na hrvatskom, a u koparskoj na jeziku slovenskom. ${ }^{99}$ Međutim, talijanaško-talijanski zastupnici kretali su gotovo uvijek s istom ignorancijom hrvatskog življa, pa kada je Šterk jednom spomenuo hrvatski jezik, dr. Boccalari je rekao da isticanjem hrvatskog jezika pokušava „pohrvatiti Srbe i Slovence u Istri“ ${ }^{100}$ Za iredentistički pokret vladajuće većine Hrvati ni tada nisu postojali u Istri. Tako je naprimjer 1883. g. čak i u starohrvatskom i glagoljaškom Vrbniku postavljena učiteljica „,koja nije osposobljena da može obućavati na hrvatskom jeziku“. ${ }^{101}$ Dolazilo je i do aspurdnih slučajeva kada je bilo pitanje upotrebe hrvatskog jezika, kao naprimjer u vezi s odlukom o znanju jezika putujućega poljoprivrednog učitelja, kojeg je trebalo angažirati u pokrajini. Tako je F. Ravnik 1869. g. isticao da taj učitelj treba poznavati i slavenski jezik. ${ }^{102}$ Oko toga pitanja ubrzo se rasplamsao žestok sukob, jer je, između ostalih, primjerice

\footnotetext{
95 Isto, str. 20-25.

96 AHAZU, ROFB, XVI-21, str. 115.

97 O njemu usp. Božo Milanović, Hrvatski narodni preporod u Istri, II, Pazin, 1973., str. 332.

98 B. Milanović, Hrvatski, 1, n. dj., str. 270.

99 Isto, str. 271.

100 B. Lukić, Borba, n. dj., str. 131.

101 AHAZU, RODV, kut. 6, sv. 11, Vrbnik, 9. 11. 1883., prijepis zapisnika roditeljskog sastanka u ravnateljstvu muške pučke učione.

102 Atti della Dieta, 27. 10. 1869.; F. Barbalić, Prvi istarski, n. dj., str. 363.
} 
F. Vidulich ustvrdio da slavenski seljak ionako neće i ne želi koristiti nove agrotehničke mjere, te je stao na stajalište da se usluge agrarnog instruktora koriste samo u talijanskim jezičnim područjima, ${ }^{103}$ što je, zapravo, značilo da će korist od toga imati samo imućni talijanaško-talijanski posjednici. U tome smislu treba gledati i otpor hrvatskih zastupnika otvaranju poljoprivrednih škola u Kopru ili Poreču, koji su pledirali da se radije otvaraju osnovne škole. ${ }^{104}$

6.

I još nekoliko riječi o upotrebi hrvatskog (i slovenskog) jezika u samome Saboru. Kao veoma veliku rijetkost spominjemo da su 13. prosinca 1873. u zapisnik imena kastavskih mjesta Rukavac, Kućeli, Bregi i Pobri zabilježena hrvatskom grafijom. ${ }^{105}$ Isto tako treba istaknuti kao rijedak primjer da se prezime veoma borbenoga Antuna Spinčića započelo također pisati u njegovu izvorniku, za razliku od njemačkoga i talijanskog, kojim se tada pisalo. ${ }^{106}$ Međutim, hrvatski i slovenski zastupnici u tome periodu ipak se nisu usudili i govoriti na svojem materinskom jeziku. Znali su da je to iluzorno i pokušati - saborska bi apsolutna većina sasvim sigurno onemogućila bilo kakav istup koji bi glasio na jeziku većine pokrajinskog pučanstva, a koje, tvrdilo se, ionako nema svojega jezika. Toga su bili svjesni svi hrvatski i slovenski zastupnici, pa je u tom slučaju karakterističan slučaj Franje Ravnika, Slovenca, tada učitelja u gimnaziji u Kopru, koji je veoma dobro poznavao hrvatski jezik i 60-ih godina bio učitelj u Kastvu. ${ }^{107}$ On je 23. listopada 1869., pristupajući izricanju zastupničke prisege, rekao na talijanskom jeziku: „Pretpostavljam da visoki sabor dopušta svakom zastupniku pravo da raspravlja saborske predmete $u$ onom jeziku Pokrajine, kojega on bolje poznaje. Budući da dobro poznajem svoj materinski jezik koji je slavenski, a talijanski samo djelomično, mogao bih upotrebljavati prvi, ali da ne govorim zidu, i da budem razumljiv svima, svojevoljno se odričem toga svoga prava, moleći

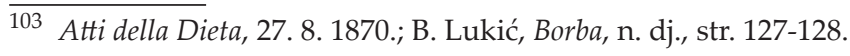

104 Vjekoslav Zidarić, Osvrt na historijski razvoj i rad Poljoprivredne škole u Pazinu do 1918., Jadranski zbornik, 5, Rijeka - Pula, 1962., str. 189-190.

105 F. Barbalić, Prvi istarski, n. dj., str. 382.

106 Isto, str. 115.

107 Maja Polić, Slovenski svećenik Franjo Ravnik kao hrvatski narodni preporoditelj, Croatica christiana Periodica, 65, Zagreb, 2010., str. 67-100; ista, O slovenskome svećeniku Franji Ravniku kao hrvatskome narodnom preporoditelju, Slovensko-hrvaško sosedstvo: Hrvatsko-slovensko susjedstvo, Kopar, 2011., str. 159-178; Maja Polić, Petar Strčić, Kalendar "Istran“ 1869. i 1870. godine. Prvo glasilo Hrvata Istre i Kvarnerskih otoka, Pazin - Rijeka, 2015. 
poštovanu gospodu, da mi oproste, ako se u talijanskom jeziku ne budem mogao izraziti s onom jasnoćom koja je potrebna u jednom parlamentu." Iznenađeni Sabor rado je prihvatio to Ravnikovo obrazloženje, a sam predsjednik, markiz Francesco de Polesini, dobrohotno je primijetio da zakon dopušta zastupniku izražavanje na njegovu jeziku, ali je ipak izrazio zadovoljstvo što će govoriti na jeziku koji svi razumiju. ${ }^{108}$ Ravnik je na fin način izrazio svoj protest, međutim tu njegovu gestu u kasnijim polemikama iredentistički je svijet znatno zloupotrebljavao pozivajući se na Ravnikov primjer prihvaćanja talijanskog jezika u saborskom radu. ${ }^{109}$ Sam Ravnik već je desetak dana kasnije (15. studenoga) spomenuo Vjekoslavu Spinčiću da je bio prvi u Saboru „koji očito kazah da sam Slovan, i da imam pravicu govoriti u saboru slovanski“" ${ }^{110}$

Zbog takvih stajališta vladajućih struktura, moguće je bilo u Istarskom saboru 60-ih i 70-ih godina zabilježiti tek nekoliko desetaka hrvatskih riječi izgovorenih za govornicom. Tako je Franjo Marotti, ${ }^{111}$ želeći 10. listopada 1871. ilustirati veoma teško ekonomsko stanje $u$ istočnoj Istri, izrecitirao cijelu jednu pjesmicu na hrvatskom jeziku, čije su riječi ušle i u saborski zapisnik. ${ }^{112}$ Zapravo, te je stihove u proznom obliku Marotti prethodno izrekao 21. svibnja 1871. u Kastavštini, na prvome hrvatskom taboru istočnootočnih Hrvata i taj je njegov tekst sačuvan u izvorniku. ${ }^{113}$ Činjenica jest da je time Marotti ušao u povijest Istarskog sabora i hrvatskoga narodnog preporoda općenito. ${ }^{114}$ Zatim je 1877. g. zastupnik Antun Spinčić - kao dokaz kako je besmisleno tražiti uvođenje talijanskog jezika u hrvatska mjesta - citirao riječi nekoga seljaka: „Kada će se opet u crikvi Majke Božje predikati po našu. ${ }^{\prime 115}$ A g. 1880. Andrija Sterk započeo je svoj govor riječima - kako kaže - „našeg pjesnika“: „Zora puca bit će dana“ želeći i na taj način pokazati kako se već s uspjehom vodi borba protiv denacionalizacije, a za

108 Atti della Dieta, 23. 10. 1869.; F. Barbalić, Prvi istarski, n. dj., str. 360-361.

109 F. Barbalić, Prvi istarski, n. dj., str. 361.

110 HDA (Hrvatski državni arhiv Zagreb) ROVS, kut. 63, g. 1869., br. 11.

111 Emilij Laszowski, Marotti Franjo, Znameniti i zaslužni Hrvati te pomena vrijedna lica u Hrvatskoj povijesti od 925-1925., Zagreb, 1925., str. 177.

112 Atti della Dieta provinciale dell'Istria in Parenzo. Resconto stenografico della VII. seduta della Dieta provinciale dell'Istria in Parenzo 10 ottobre 1871 (ore 11 antimeridiano), str. 84.

113 HDA ROVS, kut. 63, g. 1871., br. 23/1; Petar Strčić, Na velikoj prekretnici. Prvi hrvatski tabor Istre i Kvarnerskih otoka, Pula, 1989., str. 170-174.

114 Opširnije o toj pjesmi usp. P. Strčić, Na velikoj prekretnici, n. dj., str. 110-112.

115 B. Milanović, Hrvatski, 1, n. dj., str. 269. 
hrvatski jezik. ${ }^{116}$ Trebalo je, ipak, pričekati 1883. godinu, prvo zasjedanje šestoga razdoblja Istarskoga sabora, kada je - 21. kolovoza - Matko Laginja najavio na talijanskom jeziku da će govoriti na hrvatskom; i započeo je, ali je uspio reći samo: „Poštovana gospodo Latini! Izbor u Pazinu..." - i bilo je gotovo. Publika na galeriji započela je bučno protestirati, a talijanaško-talijanska većina demonstrativno je napustila dvoranu. Uzalud je Laginja protestirao da ima pravo govoriti jezikom kojim se govori u pokrajini. Tek kad je počeo govoriti na talijanskom, smirile su se strasti u sabornici, ali Laginja je, nakon izlaska iz zgrade, jedva izbjegao linč, a sutradan su on i ostali hrvatski zastupnici hitno i potajno napustili Poreč. ${ }^{117}$ Treba reći da Laginjine prve riječi u Saboru uopće nisu zabilježene u saborskom zapisniku - stenografi nisu znali hrvatski jezik i zabilježili su samo to da Laginja nešto govori na slavenskom jeziku. ${ }^{118}$ Laginja je veoma smišljeno iskoristio taj događaj - između ostalog, brzojavio je i predsjedniku austrijske vlade Taffeu, koji je namjesniku Primorja naredio istragu, pa se predsjednik Istarskog sabora F. Vidulich morao opravdavati. ${ }^{119}$ Međutim, sam potpredsjednik pokrajinske vlade i zastupnik dr. Andrea Amoroso ${ }^{120}$ sljedeće je godine otvoreno rekao, ponavljajući staro stajalište - da je u Istri vladajući samo talijanski jezik; a ako slavenski zastupnici budu govorili na svojem jeziku - jednostavno ih se neće slušati niti će se njihova izlaganja uzimati u obzir. ${ }^{121}$

Vremena su se, međutim, sasvim izmijenila - hrvatski je jezik ipak prodirao u službene forume Istre, pa se uskoro na njemu govorilo i u samome Istarskome saboru, što je bila najvidljivija potvrda o uspješnom nadograđivanju temelja hrvatskoga narodnog preporoda u tome razdoblju na jezičnome području. Pitanje upotrebe jezika u javnom, upravnom i sudskom životu Istre i otoka održavalo se stalno na površini bagateliziranjem hrvatskog jezika: „Naši protivnici nam zabavljaju i govore, da se nedadu pisati našim jezikom oporuke, ugovornice i drugi spisi, ali to je sramotna laž i poruga. ${ }^{\text {.122 }}$ Istodobno, svjesno su se minori-

\footnotetext{
$\overline{116}$ Isto, str. 270 .

117 Isto, str. 89-90.

118 Atti della Dieta, 21. 8. 1883.

119 AST, Lugotenenza del Litorale 1850-1915, atti pres idiali, fsc.123, mapa 1/2-4, dopis vlade br. 4356, 23. 8.; dopis namjesnika br. 77, 21. 8.; br. 3778, dopis F. Vidulicha, 20. 8. 1883.

120 O njemu usp. M. Szombathely, C. Pagnini, M. Cecovini, Gli avvocati di Trieste e dell'Istria nelle preparazione della redenzione, Trst, 1968., str. 50.

${ }^{121}$ Naša sloga, XV, Trst, 9. 10. 1884.

122 Naša sloga, I, 6, Trst, 16. 8. 1870., str. 3.
} 
zirala određena zakonska prava građana Istre na tome polju. Tako je naprimjer župni ured u Žminju 1873. g. odgovorio poreznom uredu u Pazinu na hrvatskom jeziku, a ovaj mu je spis vratio jer činovnici ne razumiju tekst koji je napisan na srpskom jeziku. Istom je župnom uredu i kotarsko školsko vijeće u Pazinu vratilo dopis tražeći da ga napiše na talijanskom jeziku ${ }^{123}$ Budući da to nisu bili jedini slučajevi te da su čak i niži činovnici slabo razumjeli hrvatski jezik, a još manje njime govorili, zastupnik D. Vitezić1 ${ }^{124}$ interpelirao je 1874 . g. u Carevinskom vijeću podsjećajući ministre financija, bogoštovlja i nastave na čl. XIX. državnog zakona od 21. prosinca 1867. kojim je u javnoj upravi dozvoljena uporaba i hrvatskoga jezika. Odgovor, međutim, nije stizao, pa je Vitezić urgirao, ali mu je tek 1875. g. odgovorio - i to - ministar unutarnjih poslova - da se „od financijalne oblasti poreznim uredom naredilo, da se imaju ravnati u smislu ravnopravnosti narodnoga jezika", ali da za druge slučajeve ne zna jer nema pritužbi; Ministarstvo pravosuđa još je $1862 .{ }^{125}$ i $1866 .{ }^{126}$ g. odredilo "da se rabi kod sudbenih razpravah polag potrebe slavenski jezik“; a što se tiče Vitezićeva prijedloga da se $\mathrm{u}$ Istri urede odnosi $\mathrm{u}$ vezi s uporabom jezika slično onima $\mathrm{u}$ Dalmaciji - ne bi bilo praktično jer su u Istri „mnogovrsna slavenska narječja, u kojih se govori, pa najzad i zato ne, jer tamošnje slavensko pučanstvo ne razumije pismeni slavenski jezik." ${ }^{127}$ Jasno je bilo da se sama vlada stavlja na stranu talijanaško-talijanske vladajuće strukture, da tome slijedi i potvrda iredentističkih tvrđenja: „to je izgovor naših domaćih protivnikah“ - komentira Vitezić. On i dalje u Carevinskom vijeću iznosi probleme u vezi s upotrebom jezika u uredima, pa i u vezi sa školama: „Tako se dogodilo, da se je u Istri više talijančilo

123 D. Vitezić, Poslanica, n. dj., str. 38-39.

${ }^{124}$ U AHAZU (Biblioteka „Vitezić", Vrbnik, otok Krk) RODV (Rukopisna ostavština Dinka Vitezića), kut. 11, nalazi se znatna količina građe koja govori o Vitezićevu interesu i o borbi za jezik.

125 Okružnice c. k. Prezidija Višeg zemaljskog suda u Trstu („,K. k. Oberlandesgerichtspraesidium“) od 16. 3. 1862. g. govori o zakonskom pravu slavenskog stanovništva pokrajine Primorje na primanje i izdavanje uredovnih spisa (protokola, zapisnika, dopisa, iskaza svjedoka, itd.) na narodnom jeziku na području za koje je određeni ured, odnosno nadležan sud; uredba vrijedi za sudske organe prve molbe, ukoliko su stranke slavenske nacionalnosti. Međutim, svi službenici ne moraju znati slavenske jezike. AHAZU RODV, kut. 6, sv. 11, Trst, 16. 3. 1862.

126 Niži organi nisu poštovali propise niti spomenuto uputstvo iz prethodne bilješke, a neki su smatrali da se pravo upotrebe slavenskih jezika ograničava na kaznene i nesporne pravne poslove; na to je iz Trsta 30. 10. 1866. g. opet potvrđeno ranije stajalište koje se poziva i na naredbu Ministarstva pravosuđa u Beču od 27. 1. 1866. AHAZU RODV, kut. 6, sv. 11. 
za austrijske vlade nego za bivše mletačke republike. A lahko je to rastumačiti si. Pod republikom nebijaše skoro nikakvih školah, a tim nebijaše onoga čim se najlaglje odnarodjuje." ${ }^{128}$ Doduše, vladinom odlukom 15. ožujka 1862. utvrđeno je da „imadu sudovi, u području kojih stanuju Slaveni, u slavenskom jeziku sastavljene spise bezuvjetno primati i po mogućnosti slavenskim strankam iste u njihovom jeziku rješavati“; $u$ čl. 5. toga ministarskog dekreta sudovima u Primorju dozvoljeno je „da se pribave potrebite tiskanice u slavenskom jeziku za oglase svake vrsti, dekrete za imenovanje oskrbnikah, zapisnike za svečana obećanja, smrtne propise, edikte i za poznanje jednolične odluke, da se polag toga izdaju slavenskim strankam rješitbe u slavenskom jeziku." Nova uredba (od 27. siječnja 1866.) kotarskim sudovima u Austrijskom primorju pak nalaže „da se u buduće ovom naredbom u interesu službe i samih stranaka što obilnije posluže “. ${ }^{129}$ U stvarnosti, međutim, bilo je sasvim drukčije - godine 1869. Dobrila je pisao Baltazaru Bogišiću: „Kod okružnoga suda (i kriminalnoga) u Rovinju još je tumač neki bačvar." ${ }^{\prime 130}$ A sam D. Vitezić morao je odbijanje sudskih organa da primaju dopise na hrvatskom jeziku iznositi pred nadležne u Beč, te je 1878. g. uspio da Apelacijski sud u Trstu - u skladu s nalogom Ministarstva pravosuda - izda odluku kojom se određuje da se upisi u zemljišne knjige moraju učiniti i onda kada su zatraženi na hrvatskom ili slovenskom jeziku. ${ }^{131}$

Vjekoslav Spinčić 1880. je poticao D. Vitezića da energičnije poradi u parlamentu oko obrane prava na jezik; on mu je pisao: „Gdje se hoće primati talijanske dopise, tamo se piše talijanski, gdje se toga neće, tamo se piše njemački i sili i globami udara. To znači na silu nas talijaniti." ${ }^{132}$ Vitezić je intervenirao, pa je primjerice 1883. g. zatražio od vlade da „dokine postojeće kaotične odnošaje u Istri s obzirom na jezik“. On je upozoravao da po propisima od 1835, 1862. i 1866. g. ${ }^{133}$ sudovi u Istri moraju primati tekstove koji su sastavljeni na slavenskom jeziku, ali da se to ne poštuje; zbog toga je tražio da se osnaže te ranije odluke. To je i učinjeno, pa je određeno da se u Istri (i Dalmaciji) u sudskim poslovima

\footnotetext{
$\overline{128}$ Isto, str. 41.

129 Isto, str. 44-50; isti, Druga Poslanica, n. dj., str. 43.

130 A. Marinović, Neobjavljeno, n. dj., str. 167.

131 AHAZU RODV, kut. 16, sv. 26, Žminj, 16. 11. 1877.; Beč, 8. 5. 1878.

132124 AHAZU, RODV, V. Spinčić - D. Viteziću, Kopar, 21. 1. 1884.

133 Usp. bilj. 117 i 118.
} 
mora upotrebljavati jedan od uobičajenih jezika. ${ }^{134}$ No ni ta se zakonska odredba nije poštovala, ${ }^{135}$ pa je Vitezić u parlamentu 1884. g. spominjao i slučaj nekoga kotarskog komesara koji je premješten na lošije radno mjesto jer je s hrvatskim stanovnicima uredovao na hrvatskom jeziku. Štoviše: „Ako pošalje koja hrvatska obćina kakav hrvatski spis zemaljskom odboru, može biti sigurna, da neće

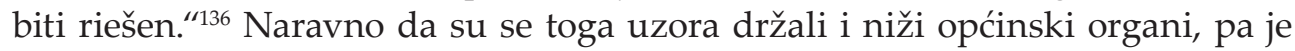
naprimjer općina na Cresu 1883. g. odbijala primiti namire ako su bile napisane hrvatskim jezikom. ${ }^{137}$

I pitanje dokumenata vezanih uz matice rođenih, vjenčanih i umrlih počelo se pretvarati u problem. Naime, prodiranje hrvatskog jezika u javnu upotrebu i očiti zahtjevi osviještenih Hrvata da im se dokumenti izdaju na suvremenom hrvatskom jeziku znatno su uznemirili talijanaško-talijanske vladajuće krugove jer je to zaista udaralo u osnovicu njihove pravne moći utemeljene na iredentističkim htijenjima. Tako je 1888. g. lošinjski kapetan dekanatskim uredima uputio dopis u kojem je označio „zlouporabom, što voditelji maticah kod izdavanja obiteljskih listovah pišu prezimena hrvatskim pravopisom a ne onako, kako je pisalo od pamtiveka (...) “'138 Gotovo svi su se župnici potužili Namjesništvu u Trstu, ali nisu dobili odgovor. Nešto slično učinio je i upravitelj porečkoga kotara. ${ }^{139}$ Tada je Vitezić intervenirao u parlamentu, ističući da se radi o glagoljskim maticama, a ne o pisanju od "pamtivijeka“, tj. talijanskim pravopisom. Pravopis se mijenja, pa tako i u hrvatskom, njemačkom, talijanskom i drugim jezicima, a samo se Hrvatima u Istri neće dozvoliti slobodna upotreba. Ministarstvo unutarnjih poslova, međutim, odredilo je da „nije dozvoljeno u izvadcih pisati imena po sada obćenito poprimljenom pravopisu niti u zaporkah, a što se novih upisivanja tiče, doista dozvoljeno je strankam zahtijevati, da se upišu pravilnim, od prijašnjeg razlikujućim načinom, nu za to mora biti sastavljen poseban protokol a taj providjen biljegom od 50 novčića. " ${ }^{410}$ Drugim riječima, za upis hrvatskim jezikom treba se posebno platiti, čime je državni sustav očito pomagao potali-

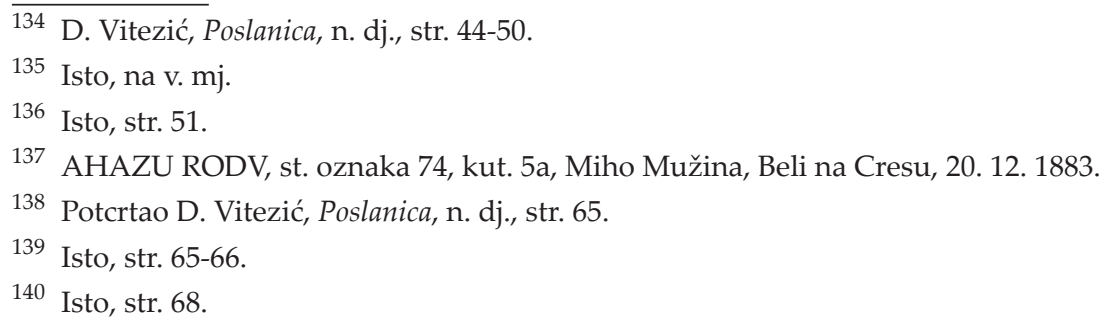


jančivanje istarsko-otočnog pučanstva i preko tako osjetljivih i temeljnih dokumenata kao što su to matične knjige. Velikih anomalija bilo je i prigodom popisa stanovništva, pa je saborski zastupnik Andrija Sterk - na primjeru „općevnog jezika" u Buzeštini - g. 1881. ustvrdio da od 1.047 stanovnika jednoga sela za njih 1.025 kaže se da se služe talijanskim kao „općevnim jezikom; međutim, u tome selu nitko nezna talijanski jezik, a u crkvi se također propovijeda na slavenskom jeziku“. ${ }^{141}$ A Vjekoslav Spinčić je 1884. g. pisao D. Viteziću da je zloupotreba bila osobito u porečkom kotaru, gdje su popisi provođeni „po najzagrizenijih Italijanomanih“ te: „Pitali su n. pr. kuće godpodara: 'ti se parlar italiano' ili što slično, a ako njin je ovaj bud što italijanski odgovorio, zabilježili su kao obćevni jezik talijanski, nesamo kuće gospodara nego i svoj njegovoj čeljadi koje nit riječi italijanski nezna“, pa su takvi prikazani kao da su talijanske narodnosti. ${ }^{142}$

8.

Bitka za jezik dakle nije mogla biti u potpunosti dobivena i zbog stajališta Beča; Bernard Stulli kaže: „Politika održavanja talijanskog kao službenog jezika, pa i kao nastavnog u školama, bitan je i neizostavan dio austrijskog upravnog sustava u Istri i Dalmaciji, sustava pogodovanja manjine na štetu hrvatske većine stanovništva. Što je takvo održavanje talijanskog jezika bilo i dalje trajno sredstvo talijanizacije dijela hrvatskog pučanstva, to austrijsku vlast nije brinulo; ona tu talijanizaciju pokušava zamijeniti jedino germanizacijom.." ${ }^{143}$ Talijanaško-talijanski predstavnici u Rijeci smatrali su 1880. g. da talijanski jezik dobro napreduje u osnovnim školama i gimnazijama Istre. ${ }^{144}$ A Vitezić je 1883. g. u parlamentu javno govorio da se Hrvati primoravaju da svoja imena pišu talijanskim pravopisom i da se u službenom dopisivanju rabi zastarjelo ime „ilirski jezik“: „Neće dakle da jezik niti pravim njegovim imenom zovu“. ${ }^{45}$ Bitku za jezik nije dovršila prva preporodna generacija. Iz druge generacije to su bili:

\footnotetext{
$\overline{141}$ AHAZU (Arhiv Hrvatske akademije znanosti i umjetnosti), ROFB, XVI-2, str. 117.

142 AHAZU RODV, kut. 6, sv. 11, V. Spinčić - D. Viteziću, 23. 4. 1884.

143 Bernard Stulli, Poreština sredinom 19. stoljeća, Vjesnik historijskih arhiva u Rijeci i Pazinu, 27, Pazin - Rijeka, 1985., str. 27-28.

144 SKP (Sveučilišna knjižnica, Pula) rukopisna građa, kut. III, sv. 64, br. 9, Gianbattista Dell’ Oste Tomasu Lucianiju, Rijeka, 20. 12. 1880.

145 D. Vitezić, Poslanica, n. dj., str. 31.
} 
Matko Laginja, ${ }^{146}$ Vjekoslav Spinčićc ${ }^{147}$ i Matko Mandić. ${ }^{148}$ Vitezić ju je započeo doslovce - već na prvom zasjedanju novoga parlamenta 1873. godine, kojemu je 6. studenoga prisustvovao prvi put; on je zatražio da se prisega čita i na hrvatskom jeziku, kao što se čita na njemačkom, poljskom, talijanskom i rumunjskom. Predsjednik je prvoga dana odgovorio da tekst nije pripravljen, a - na ponovnu Vitezićevu intervenciju, na drugoj sjednici - rekao je da nema zastupnika koji bi na tom jeziku prisegnuo. ${ }^{149}$ Vitezić je sljedeće godine predvodio delegaciju caru Franji Josipu prigodom njegova posjeta Krku te mu je tada predao pjesmu prigodnicu koja je bila napisana na hrvatskom jeziku; štoviše, Vitezić je na svojem rodnom otoku vladara pozdravio na hrvatskom jeziku (na što se vladar ispričao - kao i u Dalmaciji - što ne može odzdraviti na hrvatskome, jer ne zna dobro govoriti na tome jeziku, iako ga razumije). ${ }^{150}$

Svakako, bili su to snažni preporodni istupi u obranu prava na jezik, ali stvarne koristi u pokrajini nije bilo. Tako je Vitezić 1885. g. morao sam konstatirati tu činjenicu: „Kad se tužimo, da neimamo školah u našem jeziku, onda nam kažu: što će vam škole u jeziku, koga ste već od matere naučili i koga se ne rabi u uredih. A kad rečemo, da nam je krivo, što nam oblasti u tuđem jeziku pišu, onda nam odgovara: nije još dosta učenih ljudi, koji bi u vašem jeziku mogli

$\overline{146}$ Pučanin Matko Laginja. O 40-godišnjici smrti $18 . I I I 1930$ - 18.III 1970., Zagreb, 1969.; Petar STRČIĆ, Hrvatski narodni preporoditelj i ban dr. Matko Laginja, Zbornik Društva za povjesnicu Klana, 1, Klana, 1995., str. 9-39; Mirjana STRČIĆ, Petar STRČIĆ, Hrvatski istarski trolist, Rijeka, 1996.; Snježana MARČEC, Prilog za bibliografiju o Matku Laginji, Ivan Matetić Ronjgov. Zbornik, 5, Rijeka, 1996./1997., str. 229-237; Željko KLAIĆ, Matko Laginja između narodno-liberalne i kršćansko-socijalne struje u Istri, s osvrtom na položaj hrvatskog tiska (1918.-1928.), Zbornik Društva za povjesnicu Klana, 4, Klana, 1998., str. 37-53; Boris BILETIĆ, Političar i književnik Matko Laginja (o 70. obljetnici smrti), Nova Istra, 5, 1/2 (15), Pula, 2000., str. 157-163.

147 M. Strčić, P. Strčić, Hrvatski istarski trolist, n. dj.; Petar STRČIĆ, Političko sazrijevanje Vjekoslava Spinčića, Ivan Matetić Ronjgov. Zbornik, 5, Rijeka, 1996./1997., str. 245-260; Mile BOGOVIĆ, Vjekoslav Spinčić i staroslavensko bogoslužje u Istri, isto, str. 261-265; Mirjana STRČIĆ, Doprinos Vjekoslava Spinčića hrvatskoj književnoj povijesti, isto, str. 267-277; Darinko MUNIĆ, Vjekoslavu Spinčiću u spomen. U povodu 150. obljetnice rođenja, Zbornik Kastavštine, 6, Rijeka, 1998., str. 181-196; Sto pedeseta obljetnica rođenja prof. Vjekoslava Spinčića. 1848.-1998., Zbornik Kastavštine, 7, Rijeka, 1999., str. 1-64.

148 Viktor CAR EMIN, Matko Mandić. Osvrt na njegov život i rad, Samobor, 1938.; M. Strčić, P. Strčić, Hroatski istarski trolist, n. dj.; Petar STRČIĆ, Politički profil Matka Mandića, Liburnijske teme, 9, Opatija, 1996., str. 30-39; isti, Prilog za biografiju Matka Mandića, Ivan Matetić Ronjgov. Zbornik, 5, Rijeka, 1996./1997., str. 301-312; Matko Mandić, Matulji, 1999.

149 AHAZU RODV, koncept Vitezićeva brzojava koji je objavljen u zadarskom Narodnom listu, XII, 90, Zadar, 8. 11. 1873.; usp. i Naša sloga, IV, 22, Trst, 16. 11. 1973, str. 3(89).

150 Naša sloga, V, 11, Trst, 1. 6. 1874., str. 1 i 2. 
službu služiti. Tako mutljaju oni, kojim se neće očito povrediti zakona. To je onaj 'circilus vitious', u kojem se prema nam naši protivnici nalaze.."151 Rješavanje je ostalo drugome naraštaju preporodnih radnika, odnosno Matku Laginji, Matku Mandiću i Vjekoslavu Spinčiću. To je najvidljivije u Istarskom saboru - g. 1883. M. Laginja pokušao je održati govor na hrvatskom jeziku, a već sljedeće godine članovi Hrvatsko-slovenskog kluba u tome Saboru donose povijesnu odluku: „Pošto smo mi rođeni Hrvati, odnosno Slovenci, pošto smo odgojeni hrvatskim ili slovenskim jezikom, pošto je nas poslao narod hrvatski ili slovenski, pošto smo mi zastupnici toga naroda u Istri, pošto se je dogodilo, da su se pojedinim našim članovima rugali, kad nisu posve korektno govorili talijanski, zato odlučujemo načelno: da ćemo se u saboru služiti hrvatskim odnosno slovenskim jezikom tim više što imamo i zakonito pravo na to. Ostaje slobodno pojedincem, da kod svojih govora kako raztumačenje italijanskim jezikom dadu. ${ }^{\prime 152}$ Činjenica je da se o jeziku tada, na početku 80-ih godina, već moglo raspravljati s drugih, oštrijih pozicija. Prije su zastupnici u Istarskome saboru uglavnom apelirali na pravednost vladajućeg sloja; sada već i stari Vitezić zahtijeva i prijeti, ne miri se s postojećom situacijom, iznosi neugodne primjere pred široku javnost Monarhije, pa već i uspijeva s ponekim svojim zahtjevom. On otkriva veoma neugodne slučajeve upravnoga i sudskog sustava Monarhije, to čini pedantno, precizno, pravnički, tako da mu vladini organi teško mogu parirati, a u svojim istupima sve je sigurniji, jer je i njegova preporodna baza sve šira i odlučnija. Još se moglo u nizu slučajeva - u pojedinačnim primjerima - zanemariti hrvatski jezik, ali generalno uzevši - od početka 80-ih godina i na tome polju iredentistički vladajući talijanaško-talijanski sloj prelazio je u defenzivu. Dakle, pripremivši teren, prvi je naraštaj hrvatskoga narodnog pokreta i u pogledu bitke za jezik ispunio svoju preporodnu zadaću. Fomalno, javno se hrvatskim jezikom progovorilo tek 1889. godine, kada je prvi put potpredsjednik Sabora postao advokat - dr. Ante Dukić, koji je svoj pozdravni govor održao na hrvatskom jeziku; to je učinio i vladin zastupnik. ${ }^{153}$

\footnotetext{
$\overline{151}$ Isto, str. 37.

152 Vjekoslav Bratulić, Zapisnici sjednica 'Hrvatsko-slovenskog kluba' zastupnika u Istarskom saboru (1884-1901), Vjesnik historijskog arhiva u Rijeci i Pazinu, 11-12, Rijeka, 1966. - 1967., str. 136.

153 Naša sloga, XX, Trst, 10. i 17. 10. 1889.
} 
9.

U pokrajini Istri s Kvarnerskim otocima, u okviru hrvatskoga preporodnog pokreta, pitanje jezika intenziviralo se revolucionarne 1848. g. inicijativom talijanaško-talijanskih zastupnika, koji su se ministru unutarnjih poslova Habsburške Monarhije obratili sa zahtjevom da se u javnu službu i škole umjesto službenoga njemačkog uvede talijanski jezik. Prijedlog je odbijen, a uskoro je pristigao i prijedlog Kastavaca da se u javni život uvede ilirsko-hrvatski jezik, ali ni to nije zaživjelo. Zahtjev je ležao na čvršćim premisama utemeljenim na tradicijama ilirskoga pokreta u hrvatskim zemljama u cjelini. Presudna je uloga bila i biskupa Jurja Dobrile oko nakladničkih pothvata na hrvatskome jeziku. Prvi javni sudari oko dviju navedenih koncepcija - talijanaško-talijanske i hrvatske dogodili su se na prvim sjednicama Istarskoga sabora, pogotovo nakon travnja 1861. g., kada je tršćansko-koparski biskup dr. Bartolomej Jernej Legat kao virilni zastupnik već u samim počecima rada toga tijela zatražio da među pokrajinskim činovnicima bude netko tko poznaje i slovenski i ilirski dijalekt, jer u Istri ima Slavena koji ne poznaju talijanski jezik. Iako ga je podržao i krčki biskup dr. Ivan Josip Vitezić, talijanska nadmoćna većina glatko je odbila taj prvi pokušaj da se u Saboru legalizira upotreba hrvatskoga i slovenskog jezika u pokrajini. Hrvatski su zastupnici nastavili s ofenzivnim akcijama ističući da su Slaveni većina pučanstva u pokrajini, pa više ne prigovaraju samo stoga što se saborski zapisnik vodi isključivo na talijanskom jeziku već traže da i sam Sabor s većinom, tj. sa Slavenima iz pokrajine, kontaktira na njihovu jeziku; zahtijeva se i da se zapisnici objavljuju na talijanskom i slavenskom jeziku u službenom listu Osservatore Triestino. Naravno, ti su pokušaji završili s neuspjehom, iako je i poneki talijanaško-talijanski zastupnik bio svjestan da postoje i čisto slavenske općine u Istri, u kojima je nepoznat talijanski jezik, čime su se javno dematirale tvrdnje drugih iredentista da je talijanski zahvatio cijelu Istru. Borba za jezik nastavljala se jer je označavala i nastojanje da se postigne i kulturna i politička ravnopravnost te da se spriječi denacionalizacija hrvatskog življa, koja je bila u tijeku. U tome smislu treba shvatiti i nastojanje da se stipendije ne daju samo onima koji polaze gimnaziju u Istri već i onima koji se školuju u hrvatskim školama Rijeke i Senja. Biskup Dobrila nerijetko je to rješavao i osobno, iz svojih biskupijskih sredstava ili namjenskih sredstava namjesništva u Trstu. Godine 1870. donesena je uredba da se u prijelaznom roku od dvije godine i svećeničke pomoćne škole pretvore u svjetovne, a od 1872. g. učitelje imenuje pokrajinska uprava u Poreču. Dakle, cijeli je školski sustav od tada pod punom kontrolom vladajućega talija- 
naško-talijanskog sloja u Istri i na Kvarnerskim otocima. S obzirom na činjenicu da su u to doba svećenici bili gotovo jedini nosioci preporodnog pokreta, nova organizacija školskog sustava značila je pravu katastrofu za hrvatski i slovenski narod. S obzirom na to da svećenici nisu smjeli podučavati, a hrvatskih i slovenskih učitelja nije bilo, dogodilo se da je samo u tršćanskom području odjednom bilo zatvoreno četrdeset hrvatskih i slovenskih škola. Važan korak bila je i zapisnička zabilježba hrvatskom grafijom kastavskih mjesta Rukavac, Kućeli, Bregi i Pobri 1873. godine te rijedak primjer da se prezime veoma borbenoga Antuna Spinčića započelo također pisati u njegovu izvorniku. Međutim, hrvatski i slovenski zastupnici u tome periodu ipak se nisu usudili i govoriti na svojem materinskom jeziku. Znali su da je to iluzorno i pokušati jer saborska bi apsolutna većina sasvim sigurno onemogućila bilo kakav istup koji bi glasio na jeziku većine pokrajinskog pučanstva, a koje, tvrdilo se, ionako nema svojega jezika. Bitka za jezik dakle nije mogla biti u potpunosti dobivena i zbog stajališta Beča. Talijanaško-talijanski predstavnici u tadašnjoj Rijeci smatrali su 1880. g. da talijanski jezik dobro napreduje u osnovnim školama i gimnazijama Istre. A Vitezić je 1883. g. u parlamentu javno govorio da se Hrvati primoravaju da svoja imena pišu talijanskim pravopisom i da se u službenom dopisivanju koriste zastarjelim imenom „ilirski jezik“. Bitku za jezik nije dovršila prva preporodna generacija. Iz druge generacije to su bili: Matko Laginja, Vjekoslav Spinčić i Matko Mandić. Formalno, javno se hrvatskim jezikom progovorilo tek 1889. godine, kada je prvi put potpredsjednik Sabora postao advokat dr. Ante Dukić, koji je svoj pozdravni govor održao na hrvatskom jeziku.

\section{Maja Polić \\ Petar Strčić \\ The Linguistic Segment of Croatian National Revival in Istria and on the Kvarner Bay Islands}

\section{Summary}

The linguistic issue within the framework of Croatian National Revival in the Province of Istria with the Kvarner Bay islands was intensified in the revolutionary year of 1848 through the activity of the following two streams: of pro-Italian and Italian minority, and of Croatian majority. The former of the two demanded for the Italian language to replace - in civil service and in schools - the official German language; whereas, contrary to this demand, the latter proposed for "Illyrian-Croatian" language 
to be introduced in the public life. Concerning the language spoken by the major part of Istrian population, Bishop Juraj Dobrila's role in relation to the publishing endeavours in Croatian language was of key importance. The first public conflicts regarding the mentioned two concepts occurred at the first sessions of Istrian Parliament. Important steps forward were the following: a remark recorded in 1873 in Croatian script used in Rukavac, Kućeli, Bregi and Pobri (settlements in the Kastav area); and a rare example of the family name of the fighter Antun Spinčić, which started to be recorded in its original form. Croatian and Slovenian delegates did - in that period - however not dare to speak in their mother tongue. Formally, Croatian language was for the first time used in public in 1889, when the then elected Deputy Speaker of Parliament, Dr. Ante Dukić, attorney-at-law, held his welcoming speech in Croatian language.

Keywords: Croatian National Revival; the Province of Istria with the Kvarner Bay islands; linguistic issue; Istrian Parliament; Juraj Dobrila. 